\title{
Impact of Salicylic Acid and PGPR on the Drought Tolerance and Phytoremediation Potential of Helianthus annus
}

OPEN ACCESS

Edited by:

Zofia Piotrowska-Seget,

University of Silesia in Katowice,

Poland

Reviewed by:

M. Oves,

King Abdulaziz University,

Saudi Arabia

Ramprasad E. V. V.,

University of Hyderabad, India

Guy Lanza,

SUNY College of Environmental Science and Forestry, United States

${ }^{*}$ Correspondence: Naeem Khan

naeemkhan@bs.qau.edu.pk; naeemkhan001@gmail.com

Jianjun Yang

yangjianjun@caas.cn

Specialty section:

This article was submitted to Microbiotechnology, Ecotoxicology

and Bioremediation,

a section of the journal

Frontiers in Microbiology

Received: 10 July 2018 Accepted: 02 October 2018 Published: 23 October 2018

Citation:

Khan N, Zandi P, Ali S, Mehmood A, Adnan Shahid M and Yang J (2018) Impact of Salicylic Acid and PGPR on the Drought Tolerance and Phytoremediation Potential

of Helianthus annus.

Front. Microbiol. 9:2507.

doi: 10.3389/fmicb.2018.02507

\section{Naeem Khan ${ }^{1 *}$, Peiman Zandi' ${ }^{2}$, Shahid Ali ${ }^{3}$, Asif Mehmood ${ }^{4}$, Muhammad Adnan Shahid ${ }^{5}$ and Jianjun Yang ${ }^{2 *}$}

\footnotetext{
${ }^{1}$ Department of Plant Sciences, Quaid-i-Azam University, Islamabad, Pakistan, ${ }^{2}$ Institute of Environment and Sustainable Development in Agriculture, Chinese Academy of Agricultural Sciences, Beijing, China, ${ }^{3}$ Plant Epigenetics and Development Lab, Northeast Forestry University, Harbin, China, ${ }^{4}$ Department of Botany, Abdul Wali Khan University Mardan, Mardan, Pakistan, ${ }^{5}$ Horticultural Sciences Department, Institute of Food and Agricultural Sciences, University of Florida, Gainesville, FL, United States
}

The present study was aimed to isolate and characterize plant growth promoting rhizobacteria (PGPR) from the rhizosphere of rainfed area (Karak) in Pakistan. The influence of isolated rhizobacteria, in association with salicylic acid (SA), physiological attributes, drought tolerance potential, and phytoremediation in drought-stressed sunflower exposed was investigated. The isolated bacteria were named P1 and P2 and characterized on the basis of colony morphology and biochemical traits. Both PGPR P1 and P2 were identified on the basis of 16S-rRNA gene sequencing as Planomicrobium chinense strain P1 (Accession No. MF616408) and Bacillus cereus strain P2 (Accession No. MF616406). The fresh cultures (24 h old) of isolates were used to soak the seeds pre-sowing. SA was foliar applied at three-leaf-stage. Likewise, the 30-days-old seedlings (three leaf stage) were exposed to drought stress. Drought stress was imposed to 30-days-old plants (three-leaf stage) by withholding water supply for the next 15 days until the soil water content reached 10\%. The PGPR and/or SA treatment resulted in significant accumulation of $\mathrm{Cd}(84 \%), \mathrm{Pb}(66 \%)$, and $\mathrm{Ni}(65 \%)$ in the rhizosphere. PGPR also induced accumulation of $\mathrm{Cd}$ and $\mathrm{Ni}$ in plant shoot. Combined treatment of PGPR and SA increased the Cu (21\%), Co (11\%), and Zn (8\%) accumulation but decreased (12\%) the Fe accumulation as compared to coinoculation of PGPR P1 and P2. Inoculation of plants with PGPR significantly increased shoot length (60\%), root length (68\%), root fresh (61\%), and dry (63\%) biomass under water stress. The inoculated plants had increased chlorophyll (67\%), carotenoid (70\%), leaf protein (64\%), sugar (64\%), and phenolic (62\%) contents while lower leaf proline (62\%) content, malondialdehyde (MDA) (64\%), and antioxidant enzymes (67\%) which suggest their role in drought tolerance. It is concluded that integrative use of PGPR in combination with SA found to be an efficacious strategy to improve the phytoremediation of heavy metals and plant growth under stressed conditions particularly under water-deficient conditions.

Keywords: PGPR, 16S RNA gene sequencing, salicylic acid, phytoremediation, heavy metals 


\section{INTRODUCTION}

Various factors such as worldwide development, industrialization, agricultural practices, and anthropogenic activities are the most important factors responsible for soil pollution. These processes are responsible for the release of heavy metals causing serious ecological treat even if present in low concentration (Wuana and Okieimen, 2011). Recent technologies have been employed to eradicate the harmful metals from the rhizosphere which include leaching, soil excavation, fixation and landfill of the top contaminated soil but these techniques have high cost and secondary pollutants (Haque et al., 2008). Phytoremediation is an emerging in situ technology and more favorable due to its great potential. This includes the usage of plants to clean up the environments by reducing the toxicity, volume, and altering mobility of the contaminants in the soil (Shao-wei and Chang, 2004). Plants help to eliminate different pollutants such as pesticides, metals, oil, and other chemicals and play a central role in preventing the spread of contaminants through wind, rain or underground water from one area to another area. This technology comprised two important mutualistic components, i.e., plants and plant's root microbes which degrade the toxic metabolites to non-toxic metabolites (Saxena et al., 2005).

Plant growth promoting rhizobacteria (PGPR) are the inhabitant microorganisms in the rhizosphere improving the success of phytoremediation. When the PGPR are inoculated into the contaminated soil, they enhance plant's tolerance to heavy metals, accelerate the recycling of nutrients, modify toxic metals to less toxic, improve plant resistance against diseases and pest attack, and improve the soil structure (Khan and Bano, 2016; Karthik et al., 2017). The plant roots also secretes various exudates containing different free amino acids, carbohydrates, vitamins, and nutrients which are important for growth of rhizobacteria (Han et al., 2005; Babalola, 2010). PGPR serve many function for plant growth and development. They fix the atmospheric nitrogen, involved in the formation of several growth-promoting phytohormones. Moreover, the PGPR also contain enzymes that solubilize minerals which regulate plant growth (Glick et al., 1998; Ma et al., 2009; Oves et al., 2013a). In contrast to PGPR, salicylic acid (SA) is a synthetic plant growth regulator. It is economically feasible and cost effective, the SA induces systemic acquired resistance (SAR) in plants, hence protect the plants against pathogen attack and diseases, which in turn leads to improved plant growth.

Drought stress is a prevalent environmental restraint to plant growth and productivity. Drought is a meteorological term which means less water or rainfall (Khan et al., 2018). The drought stress resistance is seen in every plant but the extent is different in different plants (Jaleel et al., 2007). Water deficit and salt stresses are the global issues which effect the plant's growth, water and nutrient relations, assimilate partitioning, photosynthesis, and respiration in plants. Reports indicated water deficiency effects plant's at physiological, biochemical, and molecular characteristics such as cell division and expansion, leaf size, and fresh and dry weights (Ali et al., 2014; Glick, 2014). The key mechanisms by which PGPR encourage plant growth under stress condition includes surge in the level of endogenous ethylene concentration through 1-aminocyclopropane-1-carboxylate (ACC) deaminase enzyme, improve photosynthetic pigments, invigorating root growth, rhizoremediation, and disease resistance (Belimov et al., 2005; Madhaiyan et al., 2006).

Sunflower (Helianthus annuus L.) is an annual crop and belongs to family Asteraceae. This is a quickly growing plant and used as a target species with great potential to accumulate the heavy metals in roots, stem, and leaves. It is demonstrated that sunflower accumulates many heavy metals $(\mathrm{Zn}, \mathrm{Cu}$, and $\mathrm{Pb}$ ) in shoot. However, some reports indicates that sunflower accumulate heavy metals in roots and restrict their translocation to above ground parts (Madejon et al., 2003). It has been found that metals translocate very effectively from root to upper plant parts (Marchiol et al., 2007). It was hypothesized that PGPR and SA can improve the phytoremediation and drought tolerance potential in sunflower under water-deficient conditions. Therefore, this investigation was executed to isolate drought tolerant PGPR strains from rainfed area of Karak and then evaluate their individual role as well as in combination with SA, on the growth and phytoremediation potentials in drought-stressed sunflower. PGPR and SA enhance the process of phytoremediation and drought tolerance in plants.

\section{MATERIALS AND METHODS}

The experimental work was carried out in the green house at the Department of Plant Sciences, Quaid-i-Azam University Islamabad, Pakistan $\left(33.7294^{\circ} \mathrm{N}, 73.0931^{\circ} \mathrm{E}\right.$, average temperature of $24^{\circ} \mathrm{C}$, and humidity of $53 \%$ ) in sunflower growing season 2015-16. Seeds of sunflower (Pioneer 6480) were sown in plastic pots $(30 \mathrm{~cm} \times 40 \mathrm{~cm})$ and filled with soil and sand $(1500 \mathrm{~g})$ in a ratio of 3:1. The soil used in pots was collected from the agricultural field (sunflower) at Karak that has a pH of 6.8. The soil contained total dissolved solids (TDS) $=74 \mathrm{mg} / 50 \mathrm{ml}$, organic matter $=17.1 \mathrm{~g} / \mathrm{kg}, \mathrm{N}=1.73 \mathrm{~g} / \mathrm{kg}, \mathrm{P}=0.71 \mathrm{~g} / \mathrm{kg}$, $\mathrm{K}=19.3 \mathrm{~g} / \mathrm{kg}, \mathrm{Pb}=313.7 \mathrm{mg} / \mathrm{kg}, \mathrm{Cd}=5.7 \mathrm{mg} / \mathrm{kg}, \mathrm{Ni}=60 \mathrm{mg} / \mathrm{kg}$, $\mathrm{Zn}=1.14 \mathrm{mg} / \mathrm{kg}, \mathrm{Cu}=1.01 \mathrm{mg} / \mathrm{kg}, \mathrm{Co}=0.88 \mathrm{mg} / \mathrm{kg}$, and soil conductivity was $3.68 \mu \mathrm{S} / \mathrm{cm}$. Seeds of sunflower were washed with distilled water and surface sterilized with $95 \%$ ethanol for $2 \mathrm{~min}$ and then treated with $10 \%$ clorox before sowing. The SA was applied once at three-leaf stage $(25 \mathrm{ml} / \mathrm{pot})$. The pots were kept well-watered throughout the experiment until the start of drought stress. Pots were watered until the water seep out from the bottom of pots. Drought stress was applied at three leaf stage by withholding the supply of water for 15 days until the soil water content reached to $10 \%$. Colonies of bacterial isolates were secluded from the rhizosphere of sunflower grown in the rainfed area at Karak, Pakistan. The selected colonies were named as P1 (Planomicrobium chinense strain P1) and P2 (Bacillus cereus strain P2) and evaluated for their plant growth promoting and phytoremediation effect under water-deficient condition. The experiment was arranged as complete randomized design (CRD) with four replications. The experiment had nine treatments which are described below (Table 1): 
TABLE 1 | Experimental work plan.

\begin{tabular}{|c|c|c|c|}
\hline Symbol & Treatments & Symbol & Treatments \\
\hline $\mathrm{T} 1$ & Seeds treated with PGPR P1 & $\mathrm{T} 2$ & Seeds treated with PGPR P1 + sprayed with SA \\
\hline T3 & Seeds treated with PGPR P2 & T4 & Seeds treated with PGPR P2 + sprayed with SA \\
\hline T5 & Seeds treated with PGPR P1 and P2 & T6 & Seeds treated with PGPR P1, P2 + sprayed with SA (consortium) \\
\hline T7 & Plants treated with SA (foliar spray) & T8 & Irrigated C (uninoculated and irrigated plants) \\
\hline T9 & \multicolumn{3}{|c|}{ Stress C (uninoculated untreated plants grown under stress) } \\
\hline
\end{tabular}

Where P1: Planomicrobium chinense strain P1; P2; Bacillus cereus strain P2.

\section{Isolation and Inoculation Procedure of PGPR}

Soil samples were collected from the rhizosphere of 3-months-old sunflower plants at the depth of about $12 \mathrm{~cm}$ by uprooting the plants. The soils from the roots were collected by shaking in clean sterilized ziplock bags. The collected soil samples were immediately transported to the laboratory for decimal dilution and aliquots were transferred to the Luria Bertani (LB) media from the rhizosphere soil on which sunflower was growing. Morphologically dissimilar colonies were carefully chosen and purified with further streaking. The culture thus obtained was incubated in a shaker, centrifuged, and the obtained pellet was deferred in distilled water and the optical density (at $660 \mathrm{~nm}$ ) was adjusted to be 1, which was equal to $10^{6}$ cells $/ \mathrm{ml}$. This suspension was used for seed inoculation prior to sowing.

\section{Characterization of Bacterial Isolates Colony and Cell Morphology}

The isolates were incubated on agar plates and the final cultures (24 h old) were utilized for identification of isolated bacterial strains under microscope (Bio-Microscope XSZ-701, China). The color and shape of the colonies were recorded (Miller and Schroth, 1972).

\section{Catalase and Oxidase Test}

The catalase (CAT) and oxidase tests were performed by using the method of Steel (1961) and MacFaddin (1980). Briefly, 24-h-old bacterial cultures were dropped on the slide following the addition of $30 \%$ hydrogen peroxide (one drop). CATs were recorded based on the existence of gas bubbles (MacFaddin, 1980). To test the presence of oxidase in bacterial cell, Kovac's reagent (Kovacs, 1956) was made by the addition of hot distilled water. A strip of filter paper was immersed in this reagent and then desiccated. Twenty-four-hours-old bacterial colonies were transferred to filter paper with a color change from purple to black indicating positive peroxidase activity.

\section{Phosphorous Solubilization Index (PSI)}

The phosphorous solubilization index (PSI) was calculated as described by Pikovskaya (1948). A sterilized Petri-plate was filled with Pikovskaya's media and allowed to solidify for $30 \mathrm{~min}$. A pin point inoculum was transferred to solidified Pikovskaya media. The Pikovskaya media with inoculum was incubated at $28^{\circ} \mathrm{C}$ for 7 days. After that, the diameter of the colony was measured and the solubilization index was calculated as:

$$
\mathrm{SI}=\operatorname{diameter}(\mathrm{cm})+\text { halozone }(\mathrm{cm}) / \operatorname{diameter}(\mathrm{cm})
$$

\section{Antibacterial and Antifungal Activities}

An agar well-diffusion method was used for the determination of antibacterial activity (Navarro et al., 1996). The bacterial strains used for this study were included Staphylococcus aureus, Pseudomonas aeruginosa, Klebsiella pneumoniae, and Escherichia coli. Whereas for antifungal activity, we followed agar tube dilution method as described by Washington and Sutter (1980). The two fungal strains, i.e., Helminthosporium sativum and Fusarium solani were used for this study.

\section{Heavy Metal Tolerance}

The selected bacterial strains were tested for their resistance to heavy metals by agar dilution method (Cervantes-Vega et al., 1986). Freshly prepared agar plates were amended with various soluble heavy metal salts namely $\mathrm{Cd}, \mathrm{Pb}$, and $\mathrm{Ni}$ at various concentrations ranging from 30 to $1500 \mathrm{mg} / \mathrm{l}$ were inoculated with overnight grown cultures. Heavy metal tolerance was determined by the appearance of bacterial growth after incubating the plates at room temperature for $48 \mathrm{~h}$.

\section{Viable Cell Count Method (cfu)}

For determination of colony forming unit (cfu), decimal dilutions from the collected soil sample was made and viable cell counts were calculated as suggested by Khan and Bano (2016):

Viable cell count $(\mathrm{CFU} / \mathrm{g})=$

(no. of colonies $\times$ dilution factor/volume of inoculum)

(No. of colonies $\times$ dilution factor/volume of inoculum).

\section{Extraction of Bacterial DNA and 16S rRNA Sequence Analysis}

For extraction of bacterial DNA, tryptone yeast (TY) extract broth was inoculated with a single bacterial colony. The inoculated TY broth was incubated overnight in shaker (Model: Excella E-24). The instant grown culture was centrifuged at $12,000 \mathrm{rpm}$ for $10 \mathrm{~min}$ followed by suspending in lysis buffer. This was followed by the addition of $5 \mathrm{M} \mathrm{NaCl}(60 \mathrm{ml})$ and again centrifuged for $10 \mathrm{~min}$ at $12,000 \mathrm{rpm}$. The supernatant was shifted into a new tube trailed by the addition of chloroform. The centrifugation was done two times after adding 100\% ethanol to clean the attained DNA. The obtained DNA was 
assessed through nanodrop spectrophotometry (260-280 nm; Chen and Kuo, 1993). The cleaned DNA was than amplified by polymerase chain reaction (PCR) following the procedure of Weisburg et al. (1991). The $1 \mathrm{~kb}$ DNA ladder (Fermentas, Germany) was used as molecular marker. The cleaned fragments of $1400 \mathrm{bp}$ were sequenced and the sequenced products were determined on an Applied BioSystems model 3730XL automated DNA sequencing system at the Macrogen, Inc., Seoul, Korea.

\section{Physiological and Biochemical Analyses of Plants \\ Chlorophyll and Leaf Proline Content}

The chlorophyll content in the leaves of sunflower was estimated by chlorophyll meter (Spad-502 plus, Serial No. 20001472 made by Konica Minolta, Japan). The Proline content of sunflower leaves was determined following the method of Bates et al. (1973).

\section{Malondialdehyde (MDA) Content}

The lipid peroxidation estimated as malondialdehyde (MDA) content was recorded by calculating the amount of MDA formed by thiobarbituric acid (TBA) reaction as defined by Cui et al. (2000).

\section{Leaf Protein Content}

Leaf protein content was estimated based on the method of Lowry et al. (1951). The leaf samples were ground in $1 \mathrm{ml}$ phosphate buffer and centrifuged at $3000 \mathrm{rpm}$. The supernatant was transferred to new tubes and total volume was made to $1 \mathrm{ml}$ by the addition of distilled water. The solution was mixed by shaking after adding reagent $C$ and $D$ and incubated for half an hour at room temperature. The absorbance of each sample was determined at $650 \mathrm{~nm}$ against different concentrations of bovine serum albumen (BSA). Protein concentration was calculated as:

Protein concentration $\mathrm{mg} / \mathrm{g}=$

K value $\times$ dilution factor $\times$ absorbance/samplewt

K value $=19.6$, dilution factor $=2$, wt. of sample $=0.1 \mathrm{~g}$

\section{Sugar Estimation}

Sugar contents were determined by the method of Dubois et al. (1956). Leaf tissues were ground with distilled water $(10 \mathrm{ml})$ then centrifuged at $3000 \mathrm{rpm}$ for $5 \mathrm{~min}$. The supernatant $(0.1 \mathrm{~mL})$ was mixed with $1 \mathrm{ml}$ phenol (80\%) and $5 \mathrm{ml}$ concentrated $\mathrm{H}_{2} \mathrm{SO}_{4}$. The absorbance was recorded at $420 \mathrm{~nm}$. The concentration of the unidentified sample was considered with reference to the standard curve made by using glucose:

$$
\begin{aligned}
& \text { Sugar concentration } \mathrm{mg} / \mathrm{g}= \\
& \text { Kvalue } \times \text { dilution factor } \times \text { absorbance } / \text { sample wt }
\end{aligned}
$$$$
\mathrm{K} \text { value }=20 \text {, dilution factor }=10 \text {, wt. of sample }=0.5 \mathrm{~g}
$$

\section{Total Phenolic Content}

Folin-Ciocalteu colorimetric method (Barka et al., 2006) was used for determination of total phenolic content. Fresh leaves (600 mg) were ground with $80 \%$ ethanol $(5 \mathrm{ml}$ ) by using homogenizer. The grounded samples were poured into $50 \mathrm{ml}$ tightly covered plastic tubes and filtered after incubating for $2 \mathrm{~h}$ at $4^{\circ} \mathrm{C}$ in the dark. Ethanol $(2.5 \mathrm{ml})$ was added to the pellet. Four replicates consisting of leaf extract $(125 \mu \mathrm{l})$, Folin-Ciocalteu reagent $(625 \mu \mathrm{l})$, and $7.5 \%$ (wt/vol) $\mathrm{Na}_{2} \mathrm{CO}_{3}(250 \mu \mathrm{l})$ were vortexed for few seconds and incubated $\left(45^{\circ} \mathrm{C}\right)$ for $15 \mathrm{~min}$ in a water bath. Phenolics were measured at $750 \mathrm{~nm}$ using gallic acid as the standard and were expressed as mM GA eq/g FW.

\section{Extraction of Antioxidant Enzymes}

A $0.5 \mathrm{~g}$ of fresh leaf tissue was used for the determination of antioxidant enzymes. The fresh leaf tissue was ground in a phosphate buffer $(5 \mathrm{~mL}$ of $50 \mathrm{mM})$ in an ice bath. Then the mixture was centrifuged for $20 \mathrm{~min}$ at $13,000 \mathrm{rpm}$. The supernatant was collected and utilized for different enzyme assays.

For peroxidase (POD, EC\# 1.11.1.x) determination, the modified method of Gorin and Heidema (1976) was used. For the determination of POD activities, an assay mixture was prepared by adding $1.35 \mu \mathrm{L}$ MES buffer ( $\mathrm{pH} 5.5$ ), $0.05 \% \mathrm{H}_{2} \mathrm{O}_{2}$, and $0.1 \%$ phenylene diamine $(1 \mu \mathrm{L})$ with an enzyme extract of $0.1 \mathrm{~mL}$. Absorbance at $485 \mathrm{~nm}$ was recorded in a spectrophotometer. Change in optical density was recorded at $485 \mathrm{~nm} / \mathrm{min}$ as one unit of POD.

We followed the procedure of Asada and Takahashi (1987) to determine ascorbate peroxidase (APOX) activity (EC\# 1.11.1.11). A reaction mixture was prepared by adding $50 \mathrm{mM} \mathrm{KH} \mathrm{KO}_{4}$ buffer, $0.5 \mathrm{mM}$ ascorbic acid, and $\mathrm{H}_{2} \mathrm{O}_{2}(0.1 \mathrm{mM})$ to a $100 \mu \mathrm{L}$ enzyme extract. A blank solution was made the same way but without the enzyme extract and absorbance was recorded at a wavelength of $290 \mathrm{~nm}$.

Catalase (EC\# 1.11.1.6) activity was estimated following the method of Chandlee and Scandalios (1984), where an assay mixture was prepared by adding KH2PO4 (1 $\mathrm{mM})$ buffer $(2.6 \mathrm{~mL})$ and $\mathrm{H}_{2} \mathrm{O}_{2}(400 \mu \mathrm{L})$ with an enzyme extract $(40 \mu \mathrm{L})$. The breakdown of $\mathrm{H}_{2} \mathrm{O}_{2}$ was an indicator of the CAT activity in the leaves and was recorded by the absorbance of light by $\mathrm{H}_{2} \mathrm{O}_{2}$ at $240 \mathrm{~nm}$, and the CAT activity was expressed in $1 \mathrm{U} / \mathrm{mg}$ protein ( $\mathrm{U}=1 \mathrm{mM}$ of $\mathrm{H}_{2} \mathrm{O}_{2}$ reduction/min/mg of protein).

\section{Determination of IAA, GA3, and ABA}

Phytohormone were extracted and purified from plant samples following the method described by Khan and Bano (2016). Methane (80\%) along with butylated hydroxyl toluene was used for crushing the fresh leaves $(1 \mathrm{~g})$. The extract was centrifuged (3000 rpm) and supernatant was dispensed with ethyl acetate. Rotary film evaporator (REF) was used to dry the ethyl acetate phase and the residues were resuspended in methanol. The obtained samples were analyzed on HPLC after filtering through Millipore filter. IAA and GA3 were extracted at 280 and $254 \mathrm{~nm}$ wavelength separately, whereas for ABA, the samples were inserted into C18 column and eluted with a linear gradient of 
methanol (30-70\%), having $0.01 \%$ acetic acid, at a flow rate of $0.8 \mathrm{ml} / \mathrm{min}$.

\section{Shoot and Root Length $(\mathrm{cm})$}

Shoot and root length was recorded for five randomly selected plants per treatment with the help of meter rod.

\section{Root Fresh and Dry Weight (g)}

The root samples were first dried at $60^{\circ} \mathrm{C}$ for $48 \mathrm{~h}$ and then both the fresh and dried root samples were weighed with the help of an electronic balance.

\section{Nutrients Analysis of Rhizosphere Soil}

Ammonium bicarbonate-diethylene triamine penta acetic acid (DTPA) method was used for the nutrient analysis (micronutrients $\mathrm{Cu}, \mathrm{Co}, \mathrm{Fe}$, and $\mathrm{Zn}$ and heavy metals $\mathrm{Cd}, \mathrm{Pb}$, and $\mathrm{Ni}$ ) of rhizosphere soil developed by Soltanpour and Schwab (1977).

\section{Nutrient Analysis of Plant Leaves}

Dried leaves $(0.25 \mathrm{~g})$ of plant sample digested in a $50 \mathrm{ml}$ flask with a solution of nitric acid, sulfuric acid and perchloric acid in a ratio of 5:1:0.1, respectively. The mixture was boiled on hot plate under a fume hood until digestion was completed, which was indicated by the presence of white fumes from the flasks. The sample was then allowed to cool by adding distilled water till a final volume of $50 \mathrm{ml}$. Whatman No. 42 filter paper was used for filtering the extract and were analyzed by atomic absorption spectrophotometer (Shimadzu AA-670) for the presence of various metals (Allen et al., 1974).

\section{Data Analysis}

The data were analyzed using SAS version. 9.1. An ANOVA was performed to determine the effect of treatments and error associated with the experiment with replications and treatments as random effects. To identify significant differences among treatments, a mean comparison was carried out by using protected LSD $(P=0.05)$ test where error mean square was used to estimate the standard error of differences between mean.

\section{RESULTS}

\section{Colony Forming Unit (cfu) of Rhizosphere Soil}

The rhizosphere of plants inoculated with $B$. cereus strain P2 exhibited greater $\mathrm{cfu}$ than that of $P$. chinense strain P1. Addition of SA increased the cfu significantly for both the PGPR. Coinoculation of P1 and P2 was more effective than their individual application. Significant increase in cfu was noted in plants from inoculated seeds and sprayed with SA followed by those having seed inoculation only (i.e., T6 followed by T5; Table 2).

\section{Antibacterial and Antifungal Activities of PGPR Isolates}

Planomicrobium chinense strain P1 and B. cereus strain P2 had significant activity against all four used bacterial strains, i.e., $S$. aureus, P. avanigadda, K. pneumoniae, and E. coli. The B. cereus strain P2 had no response against E. coli. Maximum mycelial inhibition (65\%) of $H$. sativum was observed under B. cereus strain P2. Whereas P. chinense strain P1 was less effective against $H$. sativum, but significantly (78\%) inhibited growth of F. solani (Table 3).

\section{Phosphate Solubilization Index}

Planomicrobium chinense strain $\mathrm{P} 1$ and $B$. cereus strain P2 proved $\mathrm{P}$-solubilizer but $B$. cereus strain $\mathrm{P} 2$ presented the efficient phosphorus solubilizing potential with phosphorus solubilization index of 2.99. However, phosphorus solubilization index for P. chinense strain P1 was 1.13 (Table 4).

\section{Antibiotic Resistance of Selected PGPR Strains}

Bacillus cereus strain P2 presented higher tolerance $(200 \mu \mathrm{g} / \mathrm{ml})$ to chloramphenicol than $P$. chinense strain P1 $(100 \mu \mathrm{l} / \mathrm{ml})$. Whereas both isolated PGPR species were able to tolerate streptomycin $(200 \mu \mathrm{g} / \mathrm{ml})$. The $P$. chinense strain P1 had tolerance to hygromycin B up to $150 \mu \mathrm{g} / \mathrm{ml}$ but $B$. cereus strain P2 did not tolerate beyond $100 \mu \mathrm{g} / \mathrm{ml}$ (Table 5).

\section{Heavy Metal Tolerance}

The selected PGPR strains were checked for their tolerance ability against $\mathrm{Cd}, \mathrm{Pb}$, and $\mathrm{Ni}$. Both the PGPR strains were found effective against the heavy metals and showed maximum tolerance. $P$. chinense strain P1 showed maximum tolerance (i.e., $30-1500 \mathrm{mg} / \mathrm{l}$ ) to heavy metals except $\mathrm{Ni}$ where it was ineffective beyond $1500 \mathrm{mg} / \mathrm{l}$, whereas $B$. cereus strain P2 was ineffective against $\mathrm{Pb}$ and $\mathrm{Ni}$ at concentration of $1500 \mathrm{mg} / \mathrm{l}$ (Table 6).

\section{Heavy Metal Accumulation in Rhizosphere and Plant Shoot}

There was substantial effect of treatments on the accumulation of heavy metals in the rhizosphere (Figure 1). Combined application of PGPR and SA (T6) significantly enhanced the heavy metal accumulation than stress control (T9). Both the PGPR and SA treatments enhanced Cd accumulation (84\%) in the rhizosphere but the increase was 66 and $65 \%$ for $\mathrm{Pb}$ and $\mathrm{Ni}$ as compared to stress control. The treatmental set, seeds inoculated with PGPR P2 coupled with SA (T4), and coinoculation of seeds with PGPR P1 and P2 (T5) were at par for the Cd accumulation in the rhizosphere. Seed inoculation with PGPR P1 promoted the accumulation of $\mathrm{Ni}$, whereas higher accumulation of $\mathrm{Pb}$ and Cd was recorded in the rhizosphere of plants treated with P2. Application of SA reduced the PGPR P1 and P2 induced increase in heavy metal accumulation (i.e., T1 and T3 vs T2 and T4). SA alone (T7) was found to less effective in increasing heavy metal accumulation in the rhizosphere in comparison to inoculation with PGPR. 
TABLE 2 | Colony forming unit of PGPR in the rhizosphere.

\begin{tabular}{llr}
\hline Symbol & Treatments & CFU $^{-1}$ of soil \\
\hline T1 & Seeds inoculated with P1 & $9 \times 10^{5}$ \\
T2 & Seeds inoculated with P1 and & $9.9 \times 10^{5}$ \\
& sprayed with SA & \\
T3 & Seeds inoculated with P2 & $10.4 \times 10^{5}$ \\
T4 & Seeds inoculated with P2 and & $11.1 \times 10^{5}$ \\
& sprayed with SA & \\
T5 & Seeds inoculated with P1 + P2 & $14.6 \times 10^{5}$ \\
T6 & Seeds inoculated with P1 + P2 & $14.9 \times 10^{5}$ \\
& and sprayed with SA & \\
T7 & Foliar spray of SA & $0 \times 10^{5}$ \\
T8 & Irrigated C & $0 \times 10^{5}$ \\
T9 & Stress C & $0 \times 10^{5}$
\end{tabular}

$T 1$, seeds treated with PGPR P1; T2, seeds treated with PGPR P1 and sprayed with SA; T3, seeds treated with PGPR P2; T4, seeds treated with PGPR P2 and sprayed with SA; T5, coinocualtion of PGPR P1 and P2; T6, seeds treated with PGPR P1 and P2 + sprayed with SA; T7, foliar application of SA; T8, untreated uninoculated irrigated $C$; T9, untreated uninoculated stress $C$ (P1: Planomicrobium chinense strain P1; P2; Bacillus cereus strain P2).

Foliar application of SA and PGPR significantly enhanced the $\mathrm{Cd}$ and $\mathrm{Ni}$ accumulation in the shoot of all inoculated plants over untreated uninoculated plants grown under stress condition (T9) and over irrigated control (T8) (Figure 2). Maximum increase (87 and 74\%) in $\mathrm{Cd}$ and $\mathrm{Ni}$ accumulation was recorded when PGPR and SA were mutually applied (T6) followed by the collective inoculation with P1 and P2 (T5). The collective application of PGPR and SA augmented the Pb accumulation with $60 \%$ more in shoots than those of control plants. Inoculation with $\mathrm{P} 1$, in combination with SA, (T2) was more effective (17\%) for Cd accumulation than individual inoculation with P1 (T1). Mixed inoculation of seeds with P1 and P2 was more effective for accumulating $\mathrm{Cd}$ and $\mathrm{Ni}$ than individually application with P1 or P2. All the treatments found to be ineffective in case of accumulation of $\mathrm{Pb}$. Foliar application of SA (T7) was more effective for accumulating Ni than Cd and $\mathrm{Pb}$ by enhancing the $\mathrm{Ni}$ accumulation (59\%) in shoot of plants. In general, heavy metal accumulation was significantly enhanced in combined treatment of two PGPR or PGPR in combination with SA.

\section{Micronutrient Accumulation in Rhizosphere and Plant Shoot}

All the treatments significantly enhanced the accumulation of $\mathrm{Cu}, \mathrm{Co}, \mathrm{Fe}$, and $\mathrm{Zn}$ over the control (T9) in the rhizosphere of sunflower (Figure 3). The coinoculation of PGPR P1 and P2 (T5) significantly enhanced (75\%) the accumulation of Fe as compared to stress control. Combined application of PGPR and SA (T6) was more effective for increasing the $\mathrm{Cu}(81 \%)$, Co (77\%), and $\mathrm{Zn}(77 \%)$ accumulation. Plants receiving the treatment of SA and inoculated with PGPR P2 enhanced Fe and $\mathrm{Cu}$ accumulation in the rhizosphere by $76 \%$ as compared to stress control. They also had significantly enhanced (75\%) Zn and Co accumulation over control. Inoculation with PGPR P1, applied alone (T1) or with SA (T2) increased $\mathrm{Zn}$ accumulation (72\%) over stress control but was less effective for Fe. SA alone was more effective for increase in $\mathrm{Zn}(61 \%)$ and $\mathrm{Cu}(58 \%)$ accumulation but was less effective for $\mathrm{Fe}$ and $\mathrm{Co}$ accumulation in rhizosphere.

Similarly, both the SA and PGPR either used alone or in combination increased the micronutrient accumulation in shoot of plants over stress control (T9) and irrigated control (T8) (Figure 4). Combine application of PGPR and SA (T6) was the most efficacious for micronutrient accumulation in plant shoot. PGPR in combination with SA (T6) significantly increased $\mathrm{Fe}$ accumulation $(88 \%)$ in plant shoot whereas the increase was 81,79 , and $73 \%$ for $\mathrm{Cu}, \mathrm{Zn}$, and $\mathrm{Co}$, respectively, in comparison to control (T9). Inoculation with PGPR P1 and $\mathrm{P} 2$ alone or in combination significantly enhanced $(>78 \%)$ the Fe accumulation over T9. However, inoculation with PGPR P2 was more effective than PGPR P1 for $\mathrm{Cu}$ and Co accumulation, whereas P1 accumulated more $\mathrm{Zn}$ than P2. SA alone was effective for accumulating more $\mathrm{Fe}(76 \%)$ and $\mathrm{Cu}(65 \%)$ than control (T9).

\section{Chlorophyll and Carotenoids Content}

Chlorophyll and carotenoids content were significantly decreased by 64 and 47\%, respectively, in leaves of drought stressed plants than those under control (Table 7). However, plants treated with PGPR and/or SA showed lower reductions compared to untreated plants grown under drought stress. Treatments T5 (coinoculation of PGPR P1 and P2) and T6 (consortium of PGPR/SA) had significantly increased the leaf chlorophyll content even greater than control. SA alone was also effective in improving the chlorophyll content and was at par with T1 (plants treated with PGPR P1). The carotenoids content showed variable results and in all the treated plant relative to stressed and irrigated controls.

\section{Leaf Proline and MDA Contents}

The leaf proline and MDA contents were significantly enhanced in untreated plants grown under stress condition (Table 7). However, PGPR and SA treatment (T6) significantly reduced

TABLE 3 | Antibacterial and antifungal activities of selected PGPR strains.

\begin{tabular}{|c|c|c|c|c|c|c|c|}
\hline \multirow[b]{2}{*}{ S. No. } & \multicolumn{5}{|c|}{ Antibacterial activities } & \multicolumn{2}{|c|}{ Antifungal activities } \\
\hline & Isolates & S. aureus & P. aeruginosa & K. pneumoniae & E. coli & H. sativum & F. solani \\
\hline 2 & B. cereus strain P2 & + & + & + & - & $65 \%$ a & $69 \%$ b \\
\hline
\end{tabular}

Different letter (i.e., a and b) indicate significant differences $(P<0.05)$ among treatments. 
TABLE 4 | P-solubilizing activity of selected PGPR strains.

\begin{tabular}{llcc}
\hline S. No. & Isolates & $\begin{array}{c}\text { Halozone dm } \\
(\mathbf{m m})\end{array}$ & $\begin{array}{c}\text { P-solubilization } \\
\text { index }(\mathbf{m m})\end{array}$ \\
\hline 1 & P. chinense strain P1 & $0.29 \mathrm{a}$ & $1.13 \mathrm{~b}$ \\
2 & B. cereus strain P2 & $0.95 \mathrm{a}$ & $2.99 \mathrm{a}$
\end{tabular}

Different letter (i.e., $a$ and b) indicate significant differences $(P<0.05)$ among treatments.

the leaf proline and MDA contents. The maximum decrease by 65 and $64 \%$ in leaf proline and MDA contents, respectively, was noted in T6 (consortium of PGPR and SA) followed by T5 (coinoculation of PGPR P1 and P2). PGPR P1 and P2 in association with SA (i.e., T2 and T4) were more effective in reducing the proline and MDA contents than $\mathrm{P} 1$ and $\mathrm{P} 2$ used alone. Treatment T4 (PGPR P2 in association with SA) was at par with T5 for MDA content. SA alone (T7) was also effective in reducing (30 and 46\%) the leaf proline and MDA contents; however, reduction was lower than PGPR inoculation.

\section{Leaf Protein, Sugar, and Phenolics Content}

Drought stress caused significant changes in leaf protein, sugar, and phenolics content in sunflower leaves (Table 7). The leaf protein content was decreased by $61 \%$ under drought stress compared to irrigated control, whereas the leaf sugar and phenolics content was decreased by 60 and 63\%, respectively. The combined application of PGPR and SA (T6) considerably enhanced the leaf protein, sugar, and phenolics content and the increase was even greater (8 and 10\%) than irrigated control for protein and sugar contents, whereas leaf phenolics content of T6 was at par with irrigated control. PGPR P1 was more effective for leaf protein and sugar content than P2, whereas P2 was more responsive for enhancing the leaf phenolics content. SA alone or in association with PGPR was effective in increasing the leaf protein, sugar and phenolics contents and significantly enhanced
(40,39, and 41\%) the leaf protein, sugar, and phenolics content, respectively.

\section{Antioxidant Enzymes}

Drought stresses caused significant increase in the activities of antioxidant enzymes but were minimal in the irrigated control (Table 7). Combined treatment of PGPR and SA significantly reduced the activities of antioxidants when applied alone or in combination. Combined treatment of PGPR and SA (T6) was more effective in reducing the antioxidant enzymes as compared to PGPR or SA alone. Maximum decrease (71\%) was noted in the activities of CAT and APOX, whereas the SOD activity was reduced by $60 \%$ as compared to untreated drought stress plants. Combined treatment of PGPR P1 and P2 (T5) was more effective than $\mathrm{P} 1$ and $\mathrm{P} 2$ alone and significantly reduced $(65,57$, and 53\%) the APOX, CAT, and SOD activities. Treatment T2 was at par with $\mathrm{T} 5$ and $\mathrm{T} 4=\mathrm{T} 7$ for CAT activity, whereas $\mathrm{T} 1=\mathrm{T} 4$ for APOX activity. The SA alone was also effective in reducing the CAT (49\%) and APOX (51\%) activities but was less effective in reducing the SOD activity.

\section{Growth Parameters}

Plant growth promoting rhizobacteria treatment significantly increased shoot and root length and plant biomass (Figure 5). SA alone (T7) had no significant effect on root length and root dry weight as compared to PGPR inoculated plants. Maximum increase (60 and 67\%) in shoot and root length was recorded in T6 (combined treatment of PGPR and SA) as compared to stress control (T9) though the increase was less (12 and 10\%) than irrigated control. Combined treatment of PGPR P1 and P2 was more effective for increase (61 and 65\%) in root fresh and dry weights followed by T6. Drought stress reduced (63 and 66\%) the root fresh and dry weights significantly in the test plant; however, combined treatment of PGPR P1 and P2 significantly reduced $(\leq 5 \%)$ the damage caused by drought stress. Treatment T2 was at par with T5 for shoot length and, T2 = T4 for root dry weight. Application of SA stimulated the shoot length (46\%) and root fresh weight (53\%) as compared to stress control.

TABLE 5 | Antibiotic resistance of selected PGPR strains.

\begin{tabular}{|c|c|c|c|c|c|c|c|c|c|c|c|c|c|c|c|c|c|c|c|}
\hline \multirow[t]{2}{*}{ S. No. } & \multirow[t]{2}{*}{ PGPR } & \multicolumn{6}{|c|}{ Chloramphenicol ( $\mu \mathrm{g} / \mathrm{ml})$} & \multicolumn{6}{|c|}{ Streptomycin ( $\mu \mathrm{g} / \mathrm{ml})$} & \multicolumn{6}{|c|}{ Hygromycin B ( $\mu \mathrm{g} / \mathrm{ml})$} \\
\hline & & 25 & 50 & 75 & 100 & 150 & 200 & 25 & 50 & 75 & 100 & 150 & 200 & 25 & 50 & 75 & 100 & 150 & 200 \\
\hline 1 & P. chinense strain $\mathrm{P} 1$ & + & + & + & + & - & - & + & + & + & + & + & + & + & + & + & + & + & - \\
\hline 2 & B. cereus strain P2 & + & + & + & + & + & + & + & + & + & + & + & + & + & + & + & + & - & - \\
\hline
\end{tabular}

TABLE 6 | Heavy metal tolerance ability of selected PGPR strains.

\begin{tabular}{|c|c|c|c|c|c|c|c|c|c|c|c|c|c|c|c|c|c|c|c|}
\hline \multirow[t]{3}{*}{ S. No. } & \multirow[t]{3}{*}{ PGPR } & \multicolumn{18}{|c|}{ Heavy metal tolerance (mg/l) } \\
\hline & & \multicolumn{6}{|c|}{ Cd } & \multicolumn{6}{|c|}{$\mathrm{Pb}$} & \multicolumn{6}{|c|}{$\mathbf{N i}$} \\
\hline & & 30 & 100 & 200 & 500 & 1000 & 1500 & 30 & 100 & 200 & 500 & 1000 & 1500 & 30 & 100 & 200 & 500 & 1000 & 1500 \\
\hline 1 & P. chinense strain $\mathrm{P} 1$ & + & + & + & + & + & + & + & + & + & + & + & + & + & + & + & + & + & - \\
\hline 2 & B. cereus strain P2 & + & + & + & + & + & + & + & + & + & + & + & - & + & + & + & + & + & - \\
\hline
\end{tabular}




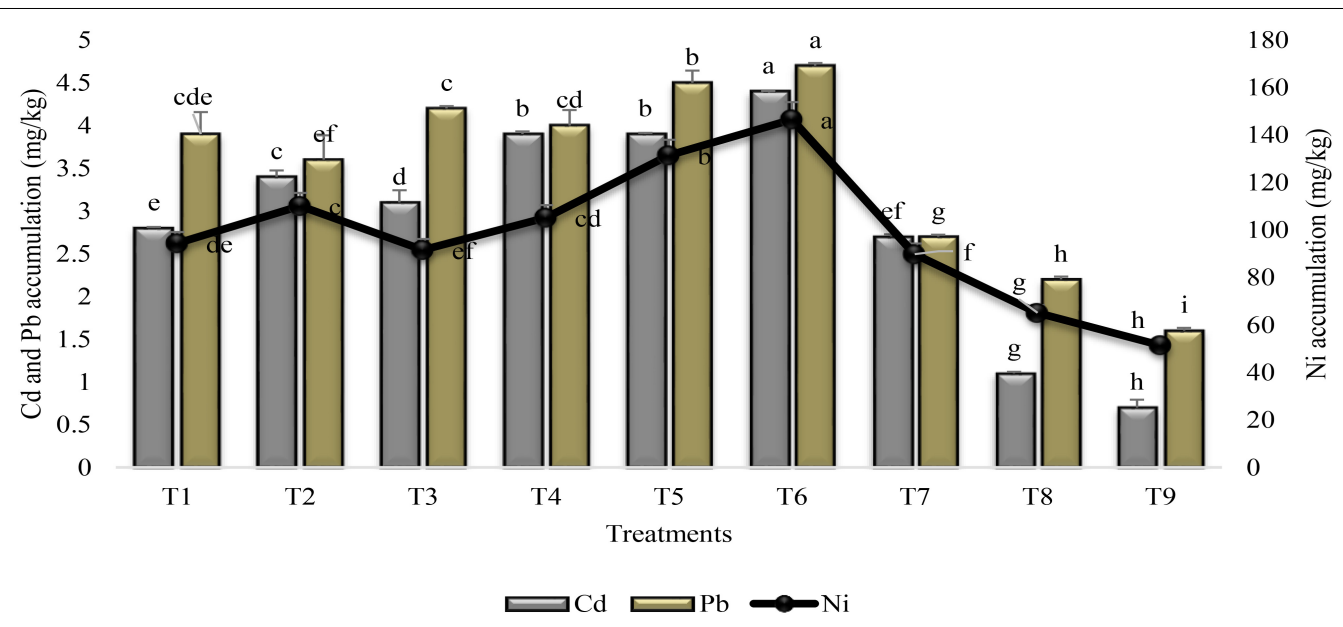

FIGURE 1 | Heavy metal accumulation in the rhizosphere of sunflower grown under drought and control conditions and treated with PGPR and SA. Error bars represent standard errors of the mean $(n=4)$ at each time point. Different letters indicate significant differences $(P<0.05)$ among treatments. T1, seeds treated with PGPR P1; T2, seeds treated with PGPR P1 and sprayed with SA; T3, seeds treated with PGPR P2; T4, seeds treated with PGPR P2 and sprayed with SA; T5, coinocualtion of PGPR P1 and P2; T6, seeds treated with PGPR P1 and P2 + sprayed with SA; T7, foliar application of SA; T8, untreated uninoculated irrigated C; T9, untreated uninoculated stress C (P1: Planomicrobium chinense strain P1; P2: Bacillus cereus strain P2).

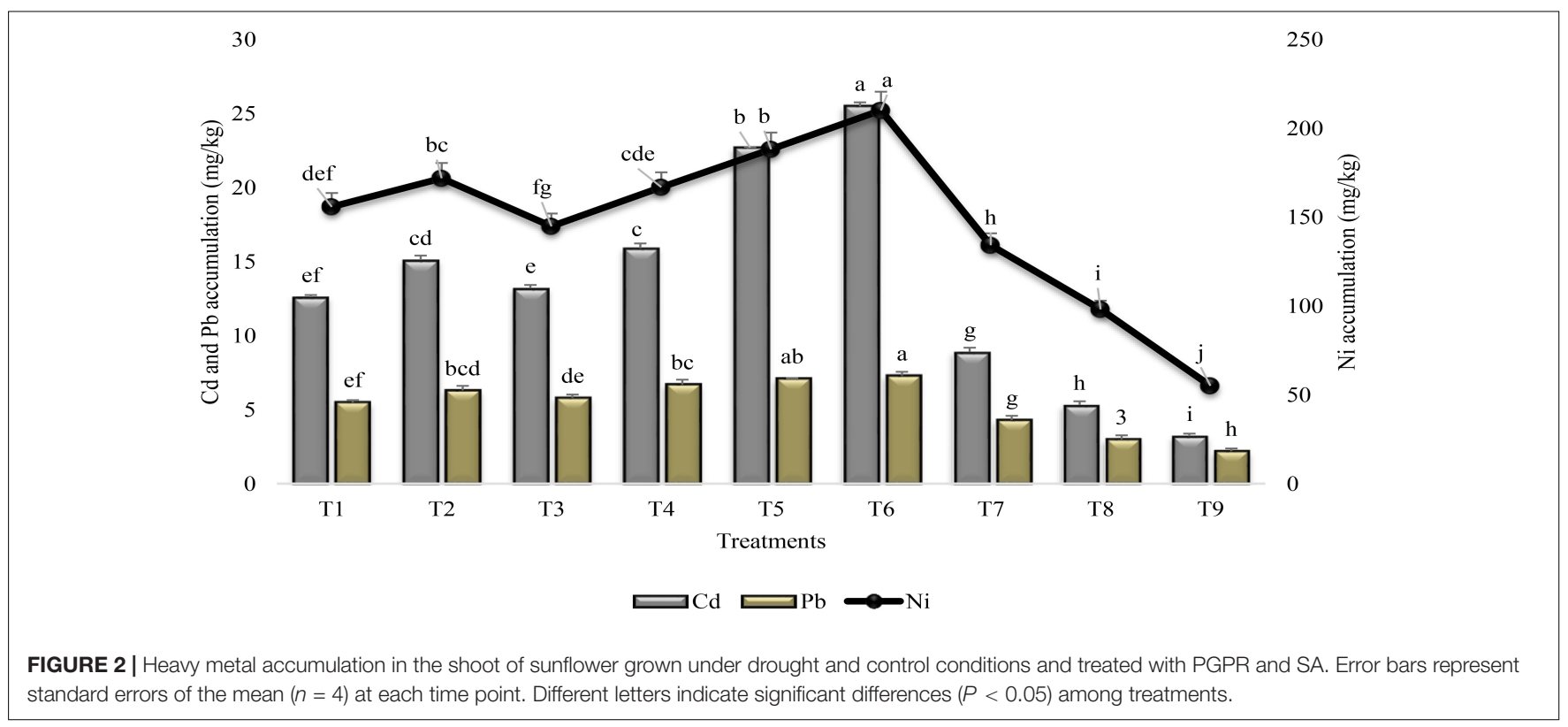

\section{IAA, GA, and ABA Content}

Phytohormones were significantly improved in response to all treatments as compared to stress and irrigated control plants (Figure 6). The mutual application of PGPR and SA (T6) increased (>70\%) the IAA, GA, and ABA content in the leaves of sunflower as compared to untreated uninoculated plants grown under drought stress condition (T9). The \% increase was higher (89\%) for GA as compared to IAA (73\%). PGPR P1 alone (T1) or in association with SA (T2) was more effective in increasing the phytohormone content than P2 (T3 and T4). Combined treatment of SA along with PGPR P1 (T2) was more effective for GA than coinoculation of P1 + P2 (T5). Foliar application of SA (T7) was more effective for increasing (81\%) the GA content, whereas the increase was 66 and $60 \%$ for $\mathrm{ABA}$ and IAA contents. Combined treatment of SA and PGPR P1 or P2 was at par with $\mathrm{P} 1$ alone and was less effective than P2 for ABA content but was more effective for IAA and GA contents.

\section{DISCUSSION}

Various anthropogenic activities are responsible for heavy metals accumulation in the environment and consequently contaminate the food chain (Ali et al., 2013). So, there is a dire need to remediate these metals by the use of various hyper-accumulators. Hyper-accumulators are capable to grow in soils having high 


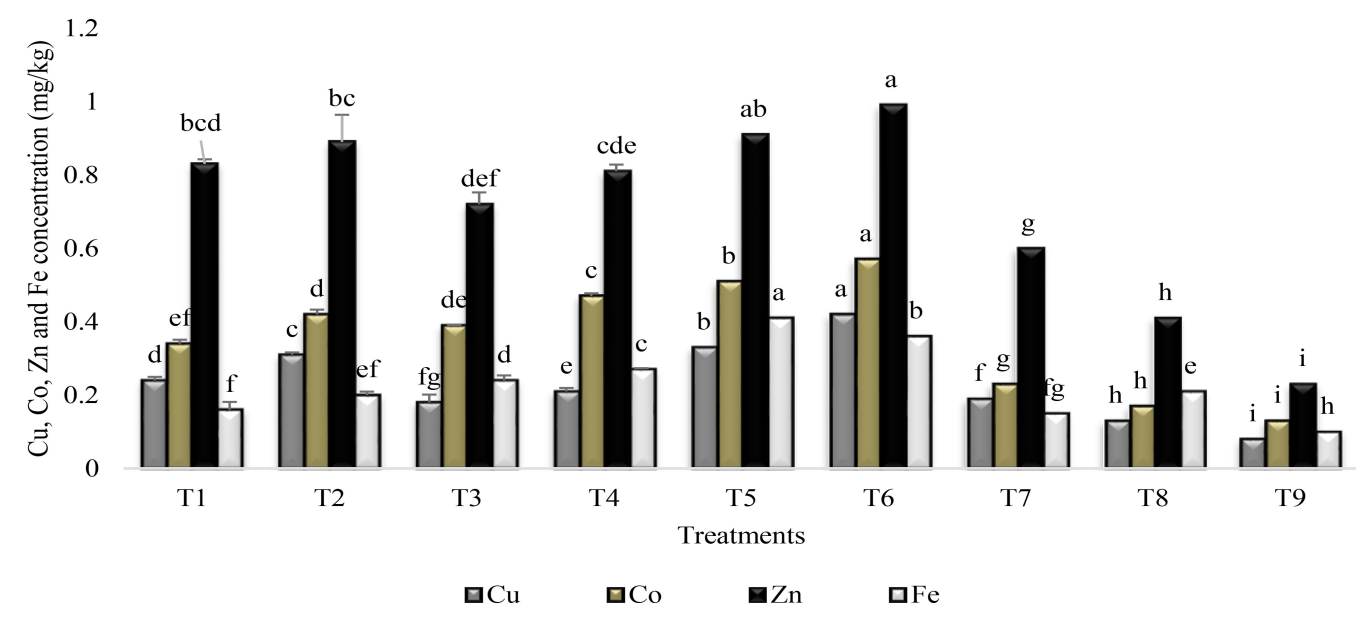

FIGURE 3 | Micronutrients accumulation in the rhizosphere of sunflower grown under drought stress and control conditions and treated with PGPR/SA. Error bars represent standard errors of the mean $(n=4)$ at each time point. Different letters indicate significant differences $(P<0.05)$ among treatments.

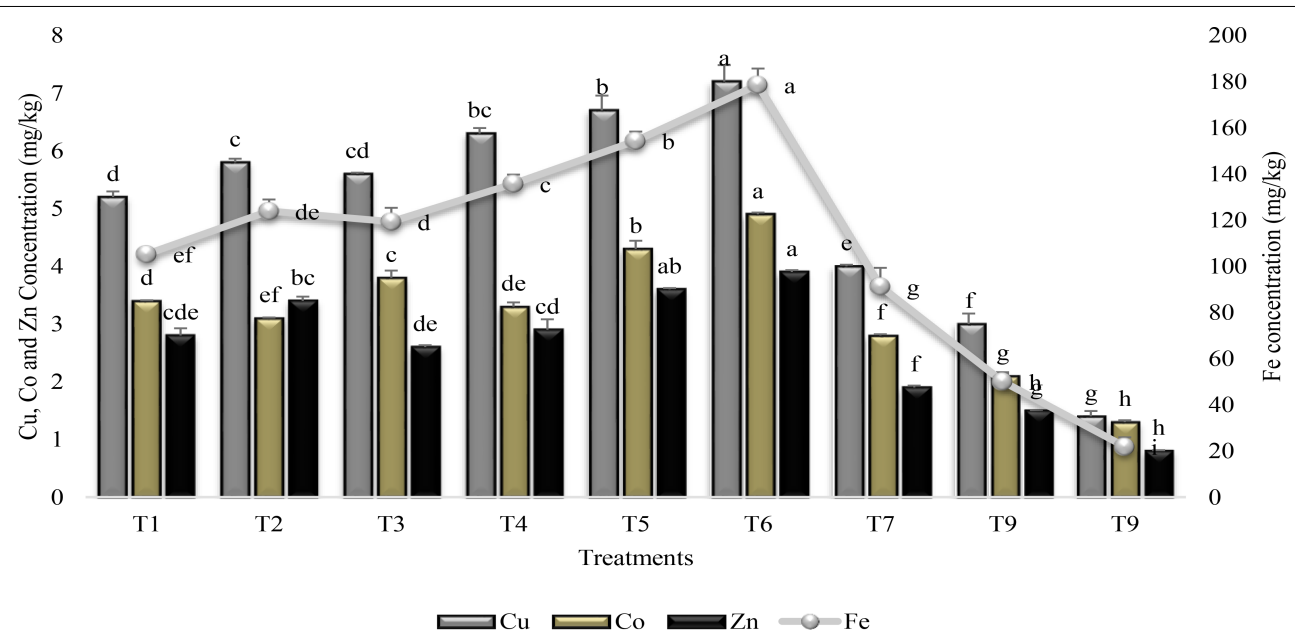

FIGURE 4 | Micronutrients accumulation in the shoot of sunflower grown under drought and control conditions and treated with PGPR and SA. Error bars represent standard errors of the mean $(n=4)$ at each time point. Different letters indicate significant differences $(P<0.05)$ among treatments.

metal concentration and have the ability to remediate the heavy metals from contaminated soils (Pence et al., 2000). Many plant species coupled with exogenous application of PGPR could be used to alleviate the toxicity caused by heavy metals (Tangahu et al., 2011). PGPR have phosphate solubilization ability and release various chelating agents thus affect the mobility and availability of various metals in the rhizosphere and enhance the process of phytoremediation and nutrient transformation. Beside this, these PGPR are also involved in plant growth, maintenance of soil structure, detoxification of hazardous chemicals, and control of plant diseases (He et al., 2007; Oves et al., 2017). In addition, plant microbe interactions provide specific $\mathrm{C}$ source to bacteria enabling them to reduce the phytotoxicity in contaminated sites (Khan and Bano, 2016).

Heavy metals toxicity in soils have been increased all over the world which alternately reduced plant growth and productivity.
Removal of heavy metals from soil can be done through various plant species (Chibuike and Obiora, 2014). PGPR inoculation efficiently alleviated the heavy metal-induced toxic effect on plant growth and development (Nadeem et al., 2014). Interestingly, significant increase in $\mathrm{Cd}$ and $\mathrm{Ni}$ contents in shoot of plants treated with 2-PGPRs and SA were (T6) measured. It is documented that SA induced tolerance to various abiotic stresses including heavy metal toxicity (Pál et al., 2002; Rivas-San Vicente and Plasencia, 2011; Oves et al., 2013b). Under stressed condition, SA contents tend to increase in roots of barley plants and induced resistance for Cd (Metwally et al., 2003) The PGPR P. chinense $\mathrm{P} 1$ was most effective in $\mathrm{Ni}$ accumulation, while $B$. cereus strain P2 augmented the accumulation of $\mathrm{Cd}$. However, inoculation mitigated the $\mathrm{Ni}$ and $\mathrm{Cd}$ toxicity more than $\mathrm{Pb}$. Both, $P$. chinense strain $\mathrm{P} 1$ and $B$. cereus strain $\mathrm{P} 2$ also had higher $\mathrm{Ni}$ and $\mathrm{Cd}$ accumulation in the rhizosphere soil compared to T8 and T9. The SA further assisted the PGPR inoculated plants to increase 
TABLE 7 | Values of leaf chlorophyll and carotenoids contents, proline, MDA, protein and phenolics content, and antioxidant enzyme activities in the leaves of sunflower.

\begin{tabular}{|c|c|c|c|c|c|c|c|c|c|c|}
\hline \multirow[t]{2}{*}{ Treatments } & Chlorophyll & Carotenoids & Proline & Protein & \multirow[t]{2}{*}{$\begin{array}{c}\text { MDA } \\
\text { (nmol/g fwt.) }\end{array}$} & \multirow[t]{2}{*}{$\begin{array}{l}\text { Sugar } \\
(\mathrm{mg} / \mathrm{g})\end{array}$} & \multirow[t]{2}{*}{$\begin{array}{l}\text { Phenolics } \\
\text { (mg GAE/g) }\end{array}$} & Catalase & APOX & SOD \\
\hline & & $(\mu \mathrm{g} / \mathrm{g})$ & & & & & & \multicolumn{3}{|c|}{ (units/g fwt.) } \\
\hline $\mathrm{T} 1$ & 33.2 & 4.3 & 0.21 & 1.6 & 0.16 & 2.9 & 2.8 & 0.27 & 0.15 & 0.39 \\
\hline $\mathrm{T} 2$ & 36.4 & 4.8 & 0.17 & 1.9 & 0.13 & 3.1 & 3.2 & 0.21 & 0.13 & 0.34 \\
\hline T3 & 31.3 & 4.6 & 0.24 & 1.4 & 0.14 & 2.4 & 3.1 & 0.31 & 0.18 & 0.43 \\
\hline $\mathrm{T} 4$ & 35.7 & 5.1 & 0.2 & 1.8 & 0.12 & 2.7 & 3.7 & 0.25 & 0.15 & 0.37 \\
\hline T5 & 39.3 & 5 & 0.16 & 2.1 & 0.12 & 3.4 & 3.9 & 0.21 & 0.12 & 0.27 \\
\hline T6 & 42.1 & 5.6 & 0.14 & 2.5 & 0.1 & 3.9 & 4.3 & 0.14 & 0.1 & 0.23 \\
\hline T7 & 33.2 & 3.9 & 0.26 & 1.5 & 0.15 & 2.3 & 2.7 & 0.25 & 0.17 & 0.42 \\
\hline T8 & 38.4 & 3.2 & 0.13 & 2.3 & 0.09 & 3.5 & 4.3 & 0.11 & 0.07 & 0.19 \\
\hline T9 & 13.9 & 1.7 & 0.37 & 0.9 & 0.28 & 1.4 & 1.6 & 0.49 & 0.35 & 0.58 \\
\hline
\end{tabular}

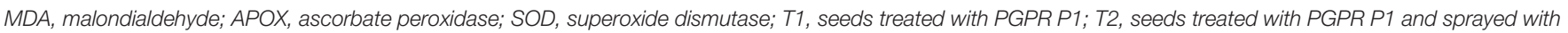

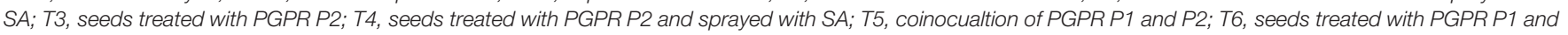

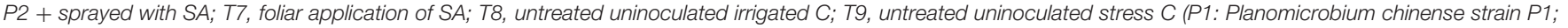
P2; Bacillus cereus strain P2).

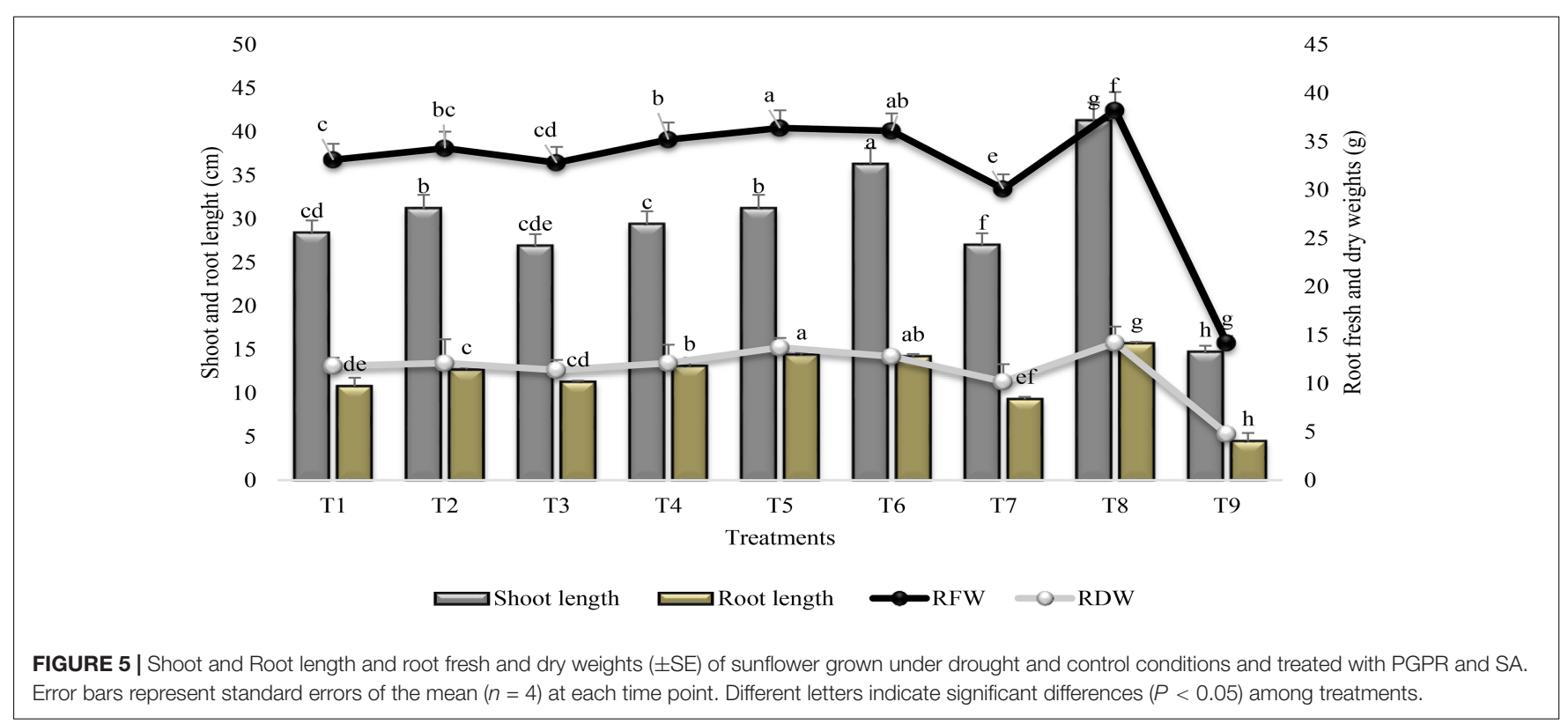

$\mathrm{Ni}, \mathrm{Pb}$, and $\mathrm{Cd}$ accumulation in the rhizosphere. Similar kind of results were observed by Sayyed et al. (2013) who reported that PGPR accelerated phytoremediation by enhancing the availability of heavy metals to the roots. Findings of Cetin et al. (2011), Tak et al. (2013), and Mishra et al. (2017) are also in accordance with our results.

It is inferred from the results obtained that the 2-PGPR $P$. chinense strain $\mathrm{P} 1$ and $B$. cereus strain $\mathrm{P} 2$ had higher $\mathrm{Cu}$ over $\mathrm{Fe}$ also have higher $\mathrm{Co}$ and $\mathrm{Zn}$ in soil and plant shoot, the effect of SA was to decrease $\mathrm{Fe}$ over $\mathrm{Cu}$ keeping the Co higher. $\mathrm{Cu}$ is an important metal for normal growth and development in plants. It controls many physiological processes, regulates homeostasis, and acts as cofactor for metalloprotiens (Yruela, 2005). It is also involved in the synthesis of various pigments and membrane integrity but it has strong binding ability with organic and inorganic colloids limiting its mobility in soil (Fernandes and Henriques, 1991). $\mathrm{Zn}$ and Co are important micronutrients that paly key role in prevention of stunt growth, chlorosis, and spikelet sterility (Singh et al., 2010; Hafeez et al., 2013). Combined application of PGPR and SA increased the accumulation of micronutrients $(\mathrm{Cu}, \mathrm{Co}$, and $\mathrm{Zn}$ ) in both the rhizosphere and shoot of plant. Similar results were recorded by Khan et al. (2017) who demonstrated that SA assists in translocation of micronutrients. Rana et al. (2012) investigated the ability of three rhizosphere bacteria for enhancing the micronutrient content in wheat plant and found significant increase in relation to control. $P$. chinense strain $\mathrm{P} 1$ and $B$. cereus strain $\mathrm{P} 2$ were shown to increase micronutrient accumulation skills of non-hyper accumulating plants by increasing biomass and growth under stress condition (Armada et al., 2015; Khan and Bano, 2016; Gupta and Kumar, 2017).

Increase in the chlorophyll and carotenoids contents in the leaves of PGPR- and SA-treated plants could be attributed to 


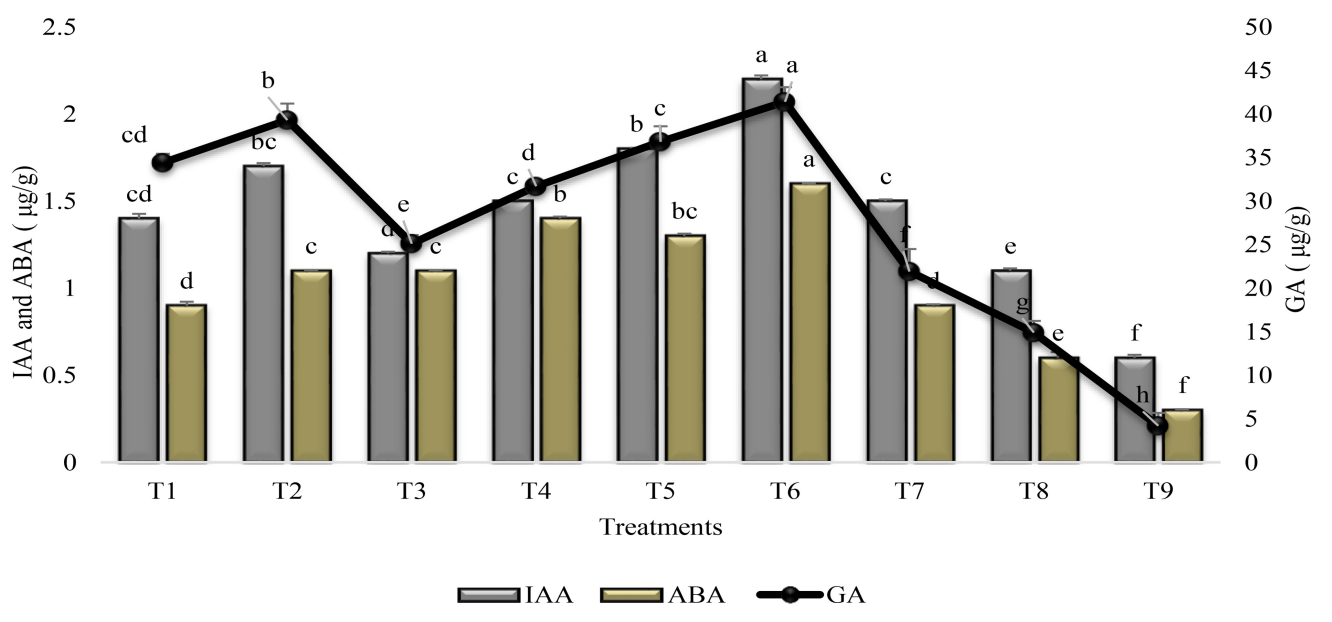

FIGURE 6 | Phytohormone content ( \pm SE) in leaves of sunflower grown under drought and control conditions and treated with PGPR and SA. Error bars represent standard errors of the mean $(n=4)$ at each time point. Different letters indicate significant differences $(P<0.05)$ among treatments.

higher availability of nutrients and increased organic matter in rhizosphere (Esitken et al., 2006; Nadeem et al., 2007). Various reports depicted that PGPR inoculation accelerates the photosynthetic pigments in plants under stress condition (Kohler et al., 2009; Bhattacharyya and Jha, 2012; Heidari and Golpayegani, 2012). Beneficial effects of foliar application of SA on plant growth, chlorophyll content, and accumulation of mineral nutrients under saline condition have also been reported by Yildirim et al. (2008). Rao et al. (1997) and Shirasu et al. (1997) reported the contributory role of SA toward light acclimation and redox homeostasis and found that SA signaling pathway contributes to achieve maximum photosynthetic activity by regulating light acclimation process and redox homeostasis. Carotenoids play a key role in protecting chlorophyll from photo-destruction and facilitate the inoffensive dissipation of excitation energy to light collecting chlorophyll antenna (Young, 1991; Demmig-Adams et al., 1996).

The suppressive effects of PGPR and SA alone or in combination on proline content was noteworthy in the present study. This probably determines the alleviation ability of the osmotic stress and maintenance of bioenergetics of cell under drought stress condition. Further decrease in proline content was obvious in combined application of PGPR and SA (T6) and almost parallel to control. So, PGPR/SA induced drought tolerance and thus no extra proline production was required. PGPR-induced decrease in proline content in leaves of maize and chickpea grown under stressed have been reported by Hameeda et al. (2008) and Khan et al. (2017). Likewise, SA-induced reduction in proline content had also been reported previously (Sakhabutdinova et al., 2003; Krantev et al., 2008). Antioxidant enzymes and MDA content were significantly enhanced under stress condition but follow-up treatment with PGPR/SA considerably lowered the activities of antioxidants and MDA content. The suppressive effect was more dominant in the consortium of PGPR and more so in combined treatment of PGPR and SA. Enhanced activities of antioxidant enzymes and MDA content may be attributed to the fact that PGPR suppress production of reactive oxygen species; consequently lower MDA content or antioxidants. Literature shows the PGPRinduced reductions in the activities of antioxidant enzymes and MDA content in many crops under different stressed conditions (Han and Lee, 2005; Jha and Subramanian, 2013; Singh et al., 2015) In this way, SA proved to be very efficacious in reducing the oxidative damage caused due to MDA content (Verma and Dubey, 1980; Tang et al., 2005; El-Halfawy and Valvano, 2014).

Plant growth promoting rhizobacteria secrete phytohormone in soil that modulates the endogenous levels of phytohormone like IAA and GA (Patten and Glick, 2002; Achard et al., 2009). These hormones are responsible for maintenance of cell division and cell elongation, thus enhance shoot length and root biomass. In this study, significant increases in IAA and GA contents in response to inoculation with PGPR or PGPR/SA consortium were recorded. IAA, which is the main auxin in plants is involved in the modulation of plant growth, embryogenesis, gametogenesis, seedling growth, cell division, flower development, and stimulate shoot elongation and root branching (Zhao, 2010). GA is also involved in the process of plant growth and development, stimulate seed germination, initiation of flowering, overcome dormancy, involved in root formation, and trigger transition from juvenile to adult stage (Mutasa-Göttgens and Hedden, 2009; Gupta and Chakrabarty, 2013). Our results are in line with Fahad et al. (2015) who reported significant increase in phytohormones in wheat plants inoculated with Bacillus species. The isolated PGPR appeared stimulatory to shoot and root length and root fresh and dry weights. Application of SA was stimulatory to root and shoot growth and further strengthen the efficacious effect of PGPR on root and shoot growth. Increased root fresh biomass by followup application of PGPR and SA could have been associated with increased root length and weight, thereby indicating that the inoculation with PGPR could result in the formation of a 
much better root system, which favorably affects shoot growth. Similar findings were investigated by Khalid et al. (2004) and Yang et al. (2009), who reported significant increases in plant root and shoot weight and leaf area in different crops inoculated with PGPR. PGPR-induced increase in shoot and root length and root fresh and dry weights had been reported in many plants (Asghar et al., 2002; Ashrafuzzaman et al., 2009; Rivas-San Vicente and Plasencia, 2011; Akhtar et al., 2018). Integrative use of PGPR with SA found to be an effective strategy for the improvement of phytoremediation and plant growth under stress condition.

The PGPR consortia (T5) used alone or in combination with SA significantly enhanced the heavy metal accumulation compared to stress control (T9). However, the consortium of two PGPR (T5) was more effective (40\%) for enhancing the accumulation of heavy metals in rhizosphere as compared to foliar application of SA alone (T7). Noteworthy, the combined treatment of two PGPR was more stimulatory for physiological parameters as compared to SA treatment made alone. But the foliar application of SA was more effective for enhancing the activity of antioxidant enzymes and proline content in the leaves of sunflower. SA in combination with PGPR act synergistically for the removal of heavy metals and plant growth and significantly enhanced the remediation abilities and growth of plant as compared to separate treatments of SA and PGPR. T6 (combined treatment of PGPR and SA) was more effective in remediating a higher \% of heavy metals as compared to T5 (consortium of two PGPR) and T7 (SA alone). PGPR/SA demonstrated multiple benefits on plant growth and yield because of their role in integrated nutrient management and root proliferation plus exopolysaccharide production (Khan et al., 2018; Naseem et al., 2018). A significant correlation was noted between the $\mathrm{Cu}, \mathrm{Co}$, $\mathrm{Fe}, \mathrm{Zn}, \mathrm{Cd}, \mathrm{Pb}$, and $\mathrm{Ni}$ of soil and shoot for T5 and T6 treatments, indicating the significance of using $\mathrm{SA}$ in combination with bacterial consortia. The accumulation of $\mathrm{Cu}, \mathrm{Co}, \mathrm{Fe}, \mathrm{Zn}$, and $\mathrm{Cd}$ was positively and significantly correlated with that of $\mathrm{Cu}, \mathrm{Co}, \mathrm{Fe}$, $\mathrm{Zn}$, and Cd $(r=0.8635, r=9238, r=8146, r=9844$, and $r=9294)$ accumulation in shoot. Chlorophyll content was positively and significantly correlated with carotenoid $(r=0.8203)$, protein $(r=9091)$, sugar $(r=9236)$, IAA $(r=8334)$, and GA $(r=3631)$ content but was negatively correlated with proline $(r=-0.9517)$, CAT $(r=-0.9504)$, APOX $(r=-0.9707)$, and SOD $(r=-0.9045)$. Carotenoids were highly significantly correlated with IAA $(r=0.8973)$, ABA $(r=0.9689)$, and GA $(r=0.9368)$. Phytohormones IAA, ABA, and GA were positively correlated with chlorophyll $(r=0.8334)$, carotenoids $(r=0.9689)$ and with $\mathrm{Cu}(r=0.9567)$, Co $(r=0.9611), \mathrm{Fe}(r=0.8035), \mathrm{Zn}$ $(r=0.9906), \mathrm{Cd}(r=0.9780)$, and $\mathrm{Pb}(r=0.9202)$ accumulation in both the rhizosphere and plant shoot. Ghazijahani et al. (2014) reported that foliar application of SA and citric acid

\section{REFERENCES}

Achard, P., Gusti, A., Cheminant, S., Alioua, M., Dhondt, S., Coppens, F., et al. (2009). Gibberellin signaling controls cell proliferation rate in Arabidopsis. Curr. Biol. 19, 1188-1193. doi: 10.1016/j.cub.2009.05.059

Akhtar, M. J., Ullah, S., Ahmad, I., Rauf, A., Nadeem, S. M., Khan, M. Y., et al. (2018). Nickel phytoextraction through bacterial inoculation in Raphanus changes the root pattern and acquisition of nutrients in the rhizosphere and thus enhances their uptake to plant shoot. Similarly, PGPR modify the root morphology, resulting in greater root surface area for the uptake of nutrients within the soil, and also protect crops against disease (Saravanakumar et al., 2008). These PGPR also produce exopolysaccharides which adhere to soil particles and also act as best matrix for retention of soil moisture, thereby protecting the roots from desiccation (Khan et al., 2017). This could be an additional benefit of PGPR/SA consortium or PGPR, that is, T6 over T5. Consortia of PGPR/SA help in maintaining chlorophyll and relative water content, thus benefiting plants grown under stress condition. It may be due to interaction between plant and beneficial microbes, which improved the nutrient uptake, increase resistance against soilborne pathogens, and reduce the effect of heavy metals (Gosling et al., 2006).

\section{CONCLUSION}

The PGPR exhibited increase in the phytoremediation of heavy metals and in the accumulation of other micronutrients. The coinoculation of two PGPR along with SA was very effective for growth parameters as well as for the phytoremediation of heavy metals. The SA in combination with PGPR was effective in enhancing tolerance of plants to drought and heavy metals. The PGPR inoculation showed inhibitory effects on proline, lipid peroxidation, and antioxidant enzymes activity. It is further inferred that the PGPR could be used to enhance the translocation and accumulation of micronutrients and heavy metals in rhizosphere and shoot of plant. The PGPR treatment was also stimulatory for the production of IAA and GA, which assist plants to tolerate stresses.

\section{AUTHOR CONTRIBUTIONS}

NK and JY designed this project. NK carried out greenhouse and lab experiments and wrote the manuscript. NK and SA performed data analysis. SA and AM improved the grammar and corrected spelling mistakes. PZ, JY, and MA edited the manuscript.

\section{FUNDING}

This study was funded by the Agricultural Science and Technology Innovation Program of Chinese Academy of Agricultural Sciences (2016-2020). The article processing charge was paid by the corresponding author.

sativus. Chemosphere 190, 234-242. doi: 10.1016/j.chemosphere.2017. 09.136

Ali, H., Khan, E., and Sajad, M. A. (2013). Phytoremediation of heavy metals-concepts and applications. Chemosphere 91, 869-881. doi: 10.1016/j. chemosphere.2013.01.075

Ali, S. Z., Sandhya, V., and Rao, L. V. (2014). Isolation and characterization of drought-tolerant ACC deaminase and exopolysaccharide-producing 
fluorescent Pseudomonas sp. Ann. Microbiol. 64, 493-502. doi: 10.1007/s13213013-0680-3

Allen, S. E., Grimshaw, H. M., Parkinson, J. A., and Quarmby, C. (1974). Chemical Analysis of Ecological Materials. Hoboken, NJ: Blackwell Scientific Publications.

Armada, E., Azcón, R., López-Castillo, O. M., Calvo-Polanco, M., and RuizLozano, J. M. (2015). Autochthonous arbuscular mycorrhizal fungi and Bacillus thuringiensis from a degraded Mediterranean area can be used to improve physiological traits and performance of a plant of agronomic interest under drought conditions. Plant Physiol. Biochem. 90, 64-74. doi: 10.1016/j.plaphy. 2015.03.004

Asada, K., and Takahashi, M. (1987). Production and Scavenging of Active Oxygens in Chloroplasts. Photoinhibition. Amsterdam: Elsevier, 227-287.

Asghar, H., Zahir, Z., Arshad, M., and Khaliq, A. (2002). Relationship between in vitro production of auxins by rhizobacteria and their growth-promoting activities in Brassica juncea L. Biol. Fertil. Soils 35, 231-237. doi: 10.1007/ s00374-002-0462-8

Ashrafuzzaman, M., Hossen, F. A., Ismail, M. R., Hoque, A., Islam, M. Z., Shahidullah, S. M., et al. (2009). Efficiency of plant growth-promoting rhizobacteria (PGPR) for the enhancement of rice growth. AJB 8.

Babalola, O. O. (2010). Bene fi cial bacteria of agricultural importance. Biotechnol. Lett. 32, 1559-1570. doi: 10.1007/s10529-010-0347-0

Barka, E. A., Nowak, J., and Clément, C. (2006). Enhancement of chilling resistance of inoculated grapevine plantlets with a plant growth-promoting rhizobacterium, Burkholderia phytofirmans strain PsJN. Appl. Environ. Microbiol. 72, 7246-7252. doi: 10.1128/AEM. 01047-06

Bates, L. S., Waldren, R. P., and Teare, I. D. (1973). Rapid determination of free proline for water-stress studies. Plant Soil 39, 205-207. doi: 10.1016/j.dental. 2010.07.006

Belimov, A. A., Hontzeas, N., Safronova, V. I., Demchinskaya, S. V., Piluzza, G, Bullitta, S., et al. (2005). Cadmium-tolerant plant growth-promoting bacteria associated with the roots of Indian mustard (Brassica juncea L. Czern.). Soil Biol. Biochem. 37, 241-250. doi: 10.1016/j.soilbio.2004.07.033

Bhattacharyya, P. N., and Jha, D. K. (2012). Plant growth-promoting rhizobacteria (PGPR): emergence in agriculture. World J. Microbiol. Biotechnol. 28, 1327-1350. doi: 10.1007/s11274-011-0979-9

Cervantes-Vega, C., Chavez, J., Cordova, N. A., and Amador, J. V. (1986). Resistance to metals by Pseudomonas aeruginosa clinical isolates. Microbios 48, $159-163$.

Cetin, S. C., Karaca, A., Kizilkaya, R., and Turgay, O. C. (2011). "Role of plant growth promoting bacteria and fungi in heavy metal detoxification," in Detoxification of Heavy Metals, eds I. Sherameti and A. Varma (Berlin: Springer), 369-388.

Chandlee, J. M., and Scandalios, J. G. (1984). Analysis of variants affecting the catalase developmental program in maize scutellum. Theor. Appl. Genet. 69, 71-77. doi: 10.1007/BF00262543

Chen, W. P., and Kuo, T. T. (1993). A simple and rapid method for the preparation of gram-negative bacterial genomic DNA. Nucleic Acids Res. 21:2260. doi: 10. 1093/nar/21.9.2260

Chibuike, G. U., and Obiora, S. C. (2014). Heavy metal polluted soils: effect on plants and bioremediation methods. Appl. Environ. Soil Sci. 2014:12. doi: 10. $1155 / 2014 / 752708$

Cui, X., Dai, X. G., Li, W. B., Zhang, B. L., and Fang, Y. Z. (2000). Effects of Lu-Duo-Wei capsules on superoxide dismutase activity and contents of malondialdehyde and lipofuscin in the brain of the housefly. Am. J. Chin. Med. 28, 259-262. doi: 10.1142/S0192415X00000301

Demmig-Adams, B., Gilmore, A. M., and Adams, W. W, III. (1996). Carotenoids 3: in vivo function of carotenoids in higher plants. FASEB J. 10, 403-412. doi: 10.1096/fasebj.10.4.8647339

Dubois, M., Gilles, K. A., Hamilton, J. K., Rebers, P. A., and Smith, F. (1956). Colorimetric method for determination of sugars and related substances. Anal. Chem. 28, 350-356. doi: 10.1021/ac60111a017

El-Halfawy, O. M., and Valvano, M. A. (2014). Putrescine reduces antibioticinduced oxidative stress as a mechanism of modulation of antibiotic resistance in Burkholderia cenocepacia. Antimicrob. Agents Chemother 58, 4162-4171. doi: 10.1128/AAC.02649-14

Esitken, A., Pirlak, L., Turan, M., and Sahin, F. (2006). Effects of floral and foliar application of plant growth promoting rhizobacteria (PGPR) on yield, growth and nutrition of sweet cherry. Sci. Hortic. 110, 324-327. doi: 10.1016/j.scienta. 2006.07.023

Fahad, S., Hussain, S., Bano, A., Saud, S., Hassan, S., Shan, D., et al. (2015). Potential role of phytohormones and plant growth-promoting rhizobacteria in abiotic stresses: consequences for changing environment. Environ. Sci. Pollut. Res. 22, 4907-4921. doi: 10.1007/s11356-014-3754-2

Fernandes, J. C., and Henriques, F. S. (1991). Biochemical, physiological, and structural effects of excess copper in plants. Botan. Rev. 57, 246-273. doi: 10. 1007/BF02858564

Ghazijahani, N., Hadavi, E., and Jeong, B. R. (2014). Foliar sprays of citric acid and salicylic acid alter the pattern of root acquisition of some minerals in sweet basil (Ocimum basilicum L.). Front. Plant Sci. 5:573. doi: 10.3389/fpls.2014.00573

Glick, B. R. (2014). Bacteria with ACC deaminase can promote plant growth and help to feed the world. Microbiol. Res. 169, 30-39. doi: 10.1016/j.micres.2013. 09.009

Glick, B. R., Penrose, D. M., and Li, J. (1998). A model for the lowering of plant ethylene concentrations by plant growth promoting bacteria. J. Theor. Biol. 190, 63-68. doi: 10.1006/jtbi.1997.0532

Gorin, N., and Heidema, F. T. (1976). Peroxidase activity in Golden Delicious apples as a possible parameter of ripening and senescence. J. Agric. Food Chem. 24, 200-201. doi: 10.1021/jf60203a043

Gosling, P., Hodge, A., Goodlass, G., and Bending, G. D. (2006). Arbuscular mycorrhizal fungi and organic farming. Agric. Ecosys. Environ. 113, 17-35. doi: 10.1016/j.agee.2005.09.009

Gupta, P., and Kumar, V. (2017). Value added phytoremediation of metal stressed soils using phosphate solubilizing microbial consortium. World J. Microbiol. Biotechnol. 33:9. doi: 10.1007/s11274-016-2176-3

Gupta, R., and Chakrabarty, S. K. (2013). Gibberellic acid in plant: still a mystery unresolved. Plant Sig. Behav. 8:e25504. doi: 10.4161/psb.25504

Han, H. S., and Lee, K. D. (2005). Physiological responses of soybean-inoculation of Bradyrhizobium japonicum with PGPR in saline soil conditions. Res. J. Agric. Biol. Sci. 1, 216-221.

Hafeez, B., Khanif, Y. M., and Saleem, M. (2013). Role of zinc in plant nutrition-a review. Am. J. Exper. Agric. 3:374. doi: 10.9734/AJEA/2013/2746

Hameeda, B., Harini, G., Rupela, O. P., Wani, S. P., and Reddy, G. (2008). Growth promotion of maize by phosphate-solubilizing bacteria isolated from composts and macrofauna. Microbiol. Res. 163, 234-242. doi: 10.1016/j.micres.2006. 05.009

Han, J., Sun, L., Dong, X., Cai, Z., Sun, X., Yang, H., et al. (2005). Characterization of a novel plant growth-promoting bacteria strain Delftia tsuruhatensi s HR4 both as a diazotroph and a potential biocontrol agent against various plant pathogens. Syst. Appl. Microbiol. 28, 66-76. doi: 10.1016/j.syapm.2004.09.003

Haque, N., Peralta-Videa, J. R., Jones, G. L., Gill, T. E., and Gardea-Torresdey, J. L. (2008). Screening the phytoremediation potential of desert broom (Baccharis sarothroides Gray) growing on mine tailings in Arizona, USA. Environ. Pollut. (Barking, Essex: 1987). 153, 362-368. doi: 10.1016/j.envpol.2007.08.024

He, Z. L., Yang, X. E., and Jing, Y. D. (2007). Role of soil rhizobacteria in phytoremediation of heavy metal contaminated soils. J. Zhejiang Univ. Sci. B 8, 192-207. doi: 10.1631/jzus.2007.B0192

Heidari, M., and Golpayegani, A. (2012). Effects of water stress and inoculation with plant growth promoting rhizobacteria (PGPR) on antioxidant status and photosynthetic pigments in basil (Ocimum basilicum L.). J. Saudi Soc. Agric. Sci. $11,57-61$.

Jaleel, C. A., Manivannan, P., Sankar, B., Kishorekumar, A., Gopi, R., Somasundaram, R., et al. (2007). Water deficit stress mitigation by calcium chloride in Catharanthus roseus; effects on oxidative stress, proline metabolism and indole alkaloid accumulation. Colloids Surf. B Biointerfaces 60, 110-116. doi: 10.1016/j.colsurfb.2007.06.006

Jha, Y., and Subramanian, R. B. (2013). Paddy plants inoculated with PGPR show better growth physiology and nutrient content under saline condition. Chil. J. Agric. Res. 73, 213-219. doi: 10.4067/S0718-58392013000300002

Karthik, C., Elangovan, N., Kumar, T. S., Govindharaju, S., Barathi, S., Oves, M., et al. (2017). Characterization of multifarious plant growth promoting traits of rhizobacterial strain AR6 under chromium (VI) stress. Microbiol. Res. 204, 65-71. doi: 10.1016/j.micres.2017.07.008

Khalid, A., Arshad, M., and Zahir, Z. A. (2004). Screening plant growth promoting rhizobacteria for improving growth and yield of wheat. J. Appl. Microbiol. 96, 473-480. doi: 10.1046/j.1365-2672.2003.02161.x 
Khan, N., and Bano, A. (2016). Role of plant growth promoting rhizobacteria and Ag-nano particle in the bioremediation of heavy metals and maize growth under municipal wastewater irrigation. Int. J. Phytomed. 18, 211-221. doi: 10. 1080/15226514.2015.1064352

Khan, N., Bano, A., and Babar, M. A. (2017). The root growth of wheat plants, the water conservation and fertility status of sandy soils influenced by plant growth promoting rhizobacteria. Symbio 72, 195-205. doi: 10.1007/s13199-016-0457-0

Khan, N., Bano, A., Rahman, M. A., Rathinasabapathi, B., and Babar MA. (2018). UPLC-HRMS based untargeted metabolic profiling reveals changes in chickpea (Cicer arietinum) metabolome following long-term drought stress. [Epub ahead of print].

Kohler, J., Hernández, J. A., Caravaca, F., and Roldán, A. (2009). Induction of antioxidant enzymes is involved in the greater effectiveness of a PGPR versus AM fungi with respect to increasing the tolerance of lettuce to severe salt stress. Environ. Exper. Bot. 65, 245-252. doi: 10.1016/j.envexpbot.2008. 09.008

Kovacs, N. (1956). Identification of Pseudomonas pyocyanea by the oxidase reaction. Nature 178:703. doi: 10.1038/178703a0

Krantev, A., Yordanova, R., Janda, T., Szalai, G., and Popova, L. (2008). Treatment with salicylic acid decreases the effect of cadmium on photosynthesis in maize plants. J. Plant Physiol. 165, 920-931. doi: 10.1016/j.jplph.2006.11.014

Lowry, O. H., Rosebrough, N. J., Farr, A. L., and Randall, R. J. (1951). Protein measurement with the Folin phenol reagent. J. Biol. Chem. 193, 265-275.

Ma, Y., Rajkumar, M., and Freitas, H. (2009). Inoculation of plant growth promoting bacteria Achromobacter xylosoxidans strain Ax10 for improvement of copper phytoextraction by Brassica juncea. J. Environ. Manage. 90, 831-837. doi: 10.1016/j.jenvman.2008.01.014

Madejon, P., Murillo, J. M., Maranon, T., Cabrera, F., and Sariano, M. A. (2003). Trace elements and nutrient accoumulation in sunflower plants two years ater then Azanacollar mine spill. Sci. Total Environ. 307, 239-257. doi: 10.1016/ S0048-9697(02)00609-5

Madhaiyan, M., Poonguzhali, S., Ryu, J., and Sa, T. (2006). Regulation of ethylene levels in canola (Brassica campestris) by 1-aminocyclopropane-1-carboxylate deaminase-containing Methylobacterium fujisawaense. Planta 224, 268-278. doi: 10.1007/s00425-005-0211-y

Marchiol. L., Fellet, G., Perosa, D., and Zerbi, G., (2007). Remove of trace metals by sorghum bicolor and heilianthus annus in a site polluted by industrial waste; a field experience. Plant Phisol. Biochem. 45, 379-387. doi: 10.1016/j.plaphy.2007. 03.018

MacFaddin, J. F. (1980). Biochemical Tests for Identification of Medical Bacteria. Baltimore, MD: Williams and Wilkins.

Metwally, A., Finkemeier, I., Georgi, M., and Dietz, K. J. (2003). Salicylic acid alleviates the cadmium toxicity in barley seedlings. Plant Physiol. 132, 272-281. doi: $10.1104 /$ pp.102.018457

Miller, T. D., and Schroth, M. N. (1972). Monitoring the epiphytic population of Erwinia amylovora. Phytopathology 62, 1175-1182. doi: 10.1111/j.1365-2672. 2011.05165.x

Mishra, J., Singh, R., and Arora, N. K. (2017). Alleviation of heavy metal stress in plants and remediation of soil by rhizosphere microorganisms. Front. Microbiol. 8:1706. doi: $10.3389 /$ fmicb.2017.01706

Mutasa-Göttgens, E., and Hedden, P. (2009). Gibberellin as a factor in floral regulatory networks. J. Exp. Bot. 60, 1979-1989. doi: 10.1093/jxb/erp040

Nadeem, S. M., Ahmad, M., Zahir, Z. A., Javaid, A., and Ashraf, M. (2014). The role of mycorrhizae and plant growth promoting rhizobacteria (PGPR) in improving crop productivity under stressful environments. Biotechnol. Adv. 32, 429-448. doi: 10.1016/j.biotechadv.2013.12.005

Nadeem, S. M., Zahir, Z. A., Naveed, M., and Arshad, M. (2007). Preliminary investigations on inducing salt tolerance in maize through inoculation with rhizobacteria containing ACC deaminase activity. Can. J. Microbiol. 53, 11411149. doi: 10.1139/W07-081

Naseem, H., Ahsan, M., Shahid, M. A., and Khan, N. (2018). Exopolysaccharides producing rhizobacteria and their role in plant growth and drought tolerance. J. Basic Microbiol. doi: 10.1002/jobm.201800309 [Epub ahead of print].

Navarro, V., Villarreal, M. L., Rojas, G., and Lozoya, X. (1996). Antimicrobial evaluation of some plants used in Mexican traditional medicine for the treatment of infectious diseases. J. Ethnopharm. 53, 143-147. doi: 10.1016/03788741(96)01429-8
Oves, M., Khan, M. S., and Qari, H. A. (2017). Ensifer adhaerens for heavy metal bioaccumulation, biosorption, and phosphate solubilization under metal stress condition. J. Taiwan Inst. Chem. Eng. 80, 540-552. doi: 10.1016/j.jtice.2017. 08.026

Oves, M., Khan, M. S., and Zaidi, A. (2013a). Biosorption of heavy metals by Bacillus thuringiensis strain OSM29 originating from industrial effluent contaminated north Indian soil. Saudi J. Biol. Sci. 20, 121-129. doi: 10.1016/ j.sjbs.2012.11.006

Oves, M., Khan, M. S., and Zaidi, A. (2013b). Chromium reducing and plant growth promoting novel strain Pseudomonas aeruginosa OSG41 enhance chickpea growth in chromium amended soils. Euro. J. Soil Biol. 56, 72-83. doi: 10.1016/j.ejsobi.2013.02.002

Pál, M., Szalai, G., Horváth, E., Janda, T., and Páldi, E. (2002). Effect of salicylic acid during heavy metal stress. Acta Biol. Szeged. 46, 119-120.

Patten, C. L., and Glick, B. R. (2002). Role of Pseudomonas putida indoleacetic acid in development of the host plant root system. Appl. Environ. Microbiol. 68, 3795-3801. doi: 10.1128/AEM.68.8.3795-3801.2002

Pence, N. S., Larsen, P. B., Ebbs, S. D., Letham, D. L., Lasat, M. M., Garvin, D. F., et al. (2000). The molecular physiology of heavy metal transport in the $\mathrm{Zn/Cd}$ hyperaccumulator Thlaspi caerulescens. Proc. Natl. Acad. Sci. U.S.A. 97, 4956-4960. doi: 10.1073/pnas.97.9.4956

Pikovskaya, R. I. (1948). Mobilization of phosphorus in soil in connection with vital activity of some microbial species. Mikrobiol 17, 362-370.

Rana, A., Joshi, M., Prasanna, R., Shivay, Y. S., and Nain, L. (2012). Biofortification of wheat through inoculation of plant growth promoting rhizobacteria and cyanobacteria. Eur. J. Soil Biol. 50, 118-126. doi: 10.1016/j.ejsobi.2012.01.005

Rao, M. V., Paliyath, G., Ormrod, D. P., Murr, D. P., and Watkins, C. B. (1997). Influence of salicylic acid on $\mathrm{H}_{2} \mathrm{O}_{2}$ production, oxidative stress, and $\mathrm{H}_{2} \mathrm{O}_{2}$-metabolizing enzymes. Plant Physiol. 115, 137-149. doi: 10.1104/pp.115. 1.137

Rivas-San Vicente, M., and Plasencia, J. (2011). Salicylic acid beyond defence: its role in plant growth and development. J. Exp. Bot. 62, 3321-3338. doi: 10.1093/ jxb/err031

Sakhabutdinova, A. R., Fatkhutdinova, D. R., Bezrukova, M. V., and Shakirova, F. M. (2003). Salicylic acid prevents the damaging action of stress factors on wheat plants. Bulg J. Plant Physiol. 29(Special Issue), 314-319.

Saravanakumar, A., Rajkumar, M., Serebiah, J. S., and Thivakaran, G. A. (2008). Seasonal variations in physico-chemical characteristics of water, sediment and soil texture in arid zone mangroves of Kachchh-Gujarat. J. Environ. Biol. 29, 725-732.

Saxena, P. N., Chauhan, L. K., and Gupta, S. K. (2005). Cytogenetic effects of formulation of cypermethrin in root meristem cells of Allium sativum: spectroscopic basis of chromosome damage. Toxicology 216, 244-252. doi: 10. 1016/j.tox.2005.08.008

Sayyed, R. Z., Patel, P. R., and Reddy, M. S. (2013). "Role of PGPR in bioremediation of heavy metal ions and plant growth-promotion of wheat and peanut grown in heavy metal contaminated soil," in Proceedings of $3 \mathrm{rd}$ Asian Conference on Plant Growth-Promoting Rhizobacteria (PGPR) and Other Microbials: Recent Advances in Biofertilizers and Biofungicides (PGPR) for Sustainable Agriculture 21-24 April, 2013 (Manila: Asian PGPR Society for Sustainable Agriculture), 112-128.

Shao-wei, L., and Chang, W. L. (2004). Heavy metal phytoremediation by water hyacinth at constructed wetlands in taiwan. J. Aquat. Plant Manage. 2, 60-68.

Shirasu, K., Nakajima, H., Rajasekhar, V. K., Dixon, R. A., and Lamb, C. (1997). Salicylic acid potentiates an agonist-dependent gain control that amplifies pathogen signals in the activation of defense mechanisms. Plant Cell 9, 261-270. doi: $10.1105 /$ tpc.9.2.261

Singh, R. P., Jha, P., and Jha, P. N. (2015). The plant-growth-promoting bacterium Klebsiella sp. SBP-8 confers induced systemic tolerance in wheat (Triticum aestivum) under salt stress. J. Plant Physiol. 184, 57-67. doi: 10.1016/j.jplph. 2015.07.002

Singh, B., Dheeravathu, S. N., and Usha, K. (2010). Micronutrient deficiency: a global challenge and physiological approach to improve grain productivity under low zinc availability. Plant Stress 4, 76-93.

Soltanpour, P. A., and Schwab, A. P. (1977). A new soil test for simultaneous extraction of macro-and micro-nutrients in alkaline soils. Commun. Soil Sci. Plant Anal. 8, 195-207. doi: 10.1080/00103627709366714 
Steel, K. J. (1961). The oxidase reaction as a taxonomic tool. Microbiology 25, 297-306.

Tak, H. I., Ahmad, F., and Babalola, O. O. (2013). Advances in the application of plant growth-promoting rhizobacteria in phytoremediation of heavy metals. Rev. Environ. Contam. Toxicol. 223, 33-52. doi: 10.1007/978-1-4614-5 577-6_2

Tang, C. F., Liu, Y. G., Zeng, G. M., Li, X., Xu, W. H., Li, C. F., et al. (2005). Effects of exogenous spermidine on antioxidant system responses of Typha latifolia L. under Cd2 + stress. J. Integr. Plant Biol. 47, 428-434. doi: 10.1111/j.1744-7909. 2005.00074.x

Tangahu, B. V., Sheikh Abdullah, S. R., Basri, H., Idris, M., Anuar, N., and Mukhlisin, M. (2011). A review on heavy metals (As, $\mathrm{Pb}$, and $\mathrm{Hg}$ ) uptake by plants through phytoremediation. Int. J. Chem. Eng. 2011:31. doi: 10.1155/2011/ 939161

Verma, S., and Dubey, R. S. (1980). Lead toxicity induces lipid peroxidation and alters the activities of antioxidant enzymes in growing rice plants. Plant Sci. 2003, 645-655.

Washington, J. A., and Sutter, V. L. (1980). Agar and microbroth dilution procedure. Am. Soc. Microbiol. 3:453.

Weisburg, W. G., Barns, S. M., Pelletier, D. A., and Lane, D. J. (1991). 16S ribosomal DNA amplification for phylogenetic study. J. Bacteriol. 173, 697-703. doi: $10.1128 /$ jb.173.2.697-703.1991

Wuana, R. A., and Okieimen, F. E. (2011). Heavy metals in contaminated soils: a review of sources, chemistry, risks and best available strategies for remediation. ISRN Ecol. 2011:20. doi: 10.5402/2011/402647
Yang, J., Kloepper, J. W., and Ryu, C. M. (2009). Rhizosphere bacteria help plants tolerate abiotic stress. Trends Plant Sci. 14, 1-4. doi: 10.1016/j.tplants.2008.10.004

Yildirim, E., Turan, M., and Guvenc, I. (2008). Effect of foliar salicylic acid applications on growth, chlorophyll, and mineral content of cucumber grown under salt stress. J. Plant Nutr. 31, 593-612. doi: 10.1080/01904160801895118

Young, A. J. (1991). The photoprotective role of carotenoids in higher plants. Physiol. Plant. 83, 702-708. doi: 10.1111/j.1399-3054.1991.tb02 490.x

Yruela, I. (2005). Copper in plants. Braz. J. Plant Physiol. 17, 145-156. doi: 10.1590/ S1677-04202005000100012

Zhao, Y. (2010). Auxin biosynthesis and its role in plant development. Annu. Rev. Plant Biol. 61, 49-64. doi: 10.1146/annurev-arplant-042809-112308

Conflict of Interest Statement: The authors declare that the research was conducted in the absence of any commercial or financial relationships that could be construed as a potential conflict of interest.

Copyright (c) 2018 Khan, Zandi, Ali, Mehmood, Adnan Shahid and Yang. This is an open-access article distributed under the terms of the Creative Commons Attribution License (CC BY). The use, distribution or reproduction in other forums is permitted, provided the original author(s) and the copyright owner(s) are credited and that the original publication in this journal is cited, in accordance with accepted academic practice. No use, distribution or reproduction is permitted which does not comply with these terms. 